\title{
A Comparative Investigation on Phenolic Composition, Characterization and Antioxidant Potentials of Five Different Australian Grown Pear Varieties
}

\author{
Zening Wang ${ }^{1}$, Colin J. Barrow ${ }^{2}\left(\mathbb{D}\right.$, Frank R. Dunshea ${ }^{1,3}$ and Hafiz A. R. Suleria ${ }^{1,2, *(\mathbb{D})}$ \\ 1 School of Agriculture and Food, Faculty of Veterinary and Agricultural Sciences, The University of \\ Melbourne, Parkville, VIC 3052, Australia; zeningw1@student.unimelb.edu.au (Z.W.); \\ fdunshea@unimelb.edu.au (F.R.D.) \\ 2 Centre for Chemistry and Biotechnology, School of Life and Environmental Sciences, Deakin University, \\ Waurn Ponds, VIC 3217, Australia; colin.barrow@deakin.edu.au \\ 3 Faculty of Biological Sciences, The University of Leeds, Leeds LS2 9JT, UK \\ * Correspondence: hafiz.suleria@unimelb.edu.au; Tel.: +61-470-439-670
}

check for updates

Citation: Wang, Z.; Barrow, C.J.; Dunshea, F.R.; Suleria, H.A.R. A Comparative Investigation on Phenolic Composition, Characterization and Antioxidant Potentials of Five Different Australian Grown Pear Varieties. Antioxidants 2021, 10, 151. https://doi.org/ 10.3390/antiox10020151

Received: 23 December 2020

Accepted: 17 January 2021

Published: 20 January 2021

Publisher's Note: MDPI stays neutral with regard to jurisdictional claims in published maps and institutional affiliations.

Copyright: (c) 2021 by the authors. Licensee MDPI, Basel, Switzerland. This article is an open access article distributed under the terms and conditions of the Creative Commons Attribution (CC BY) license (https:// creativecommons.org/licenses/by/ $4.0 /)$.

\begin{abstract}
Pear (Pyrus communis L.) is widely spread throughout the temperate regions of the world, such as China, America and Australia. This fruit is popular among consumers due to its excellent taste and perceived health benefits. Various bioactive compounds, which contribute to these health benefits, have been detected in the pear fruits, including a range of phenolic compounds. Five Australian grown pear varieties, which include Packham's Triumph, Josephine de Malines, Beurre Bosc, Winter Nelis and Rico were selected for this study to examine the phenolic compounds in pears. Beurre Bosc exhibited the highest total polyphenol content (TPC) (3.14 $\pm 0.02 \mathrm{mg} \mathrm{GAE} / \mathrm{g})$, total tannin content (TTC) $(1.43 \pm 0.04 \mathrm{mg} \mathrm{CE} / \mathrm{g})$ and 2,2'-diphenyl-1-picrylhydrazyl (DPPH) $(5.72 \pm 0.11 \mathrm{mg} \mathrm{AAE} / \mathrm{g})$, while the Josephine de Malines variety was high in total flavonoid content (TFC) $(1.53 \pm 0.09 \mathrm{mg} \mathrm{QE} / \mathrm{g})$, ferric reducing antioxidant power (FRAP) (4.37 $\pm 0.04 \mathrm{mg} \mathrm{AAE} / \mathrm{g})$, 2,2'-azinobis-(3-ethylbenzothiazoline-6-sulfonic acid) (ABTS) (4.44 $\pm 0.01 \mathrm{mg} \mathrm{AAE} / \mathrm{g}$ ) and total antioxidant capacity (TAC) $(5.29 \pm 0.09 \mathrm{mg} \mathrm{AAE} / \mathrm{g})$. The liquid chromatography coupled with electrospray-ionization quadrupole time-of-flight mass spectrometry (LC-ESI-QTOF-MS/MS) data indicate that a total of 73 phenolic compounds were detected in Beurre Bosc (37 compounds), Josephine de Malines (34), Rico (22), Packham's Triumph (15) and Winter Nelis (9), respectively. From HPLC-PDA quantification, the Beurre Bosc pear variety showed significantly higher in phenolic acids (chlorogenic acid; $17.58 \pm 0.88 \mathrm{mg} / \mathrm{g}$ ) and while flavonoids were significantly higher in Josephine de Malines (catechin; $17.45 \pm 1.39 \mathrm{mg} / \mathrm{g}$ ), as compared to other pear varieties. The analyses suggest that the Australian grown pears might contain an ideal source of phenolic compounds which benefit human health. The information provided by the present work can serve as practical supporting data for the use of pears in the nutraceutical, pharmaceutical and food industries.
\end{abstract}

Keywords: pear; phenolic compounds; antioxidant activity; LC-MS/MS; HPLC-PDA

\section{Introduction}

Pears (Pyrus communis L.) are one of the most common fruits in people's daily life. Pears are not only delicious and cheap, but they are also rich in phytochemicals [1]. Pears are grown in the temperate regions of the world which includes more than 50 countries. In 2019 , the global production of pears reached 23.1 million tons [2] with around $10 \%$ of pears production being processed into various products, such as canned pears, concentrated pear juice and fresh cut pears [3]. Pears are rich sources of bioactive compounds such as phytochemicals, soluble sugars, amino acids, vitamins and minerals [4]. Bioactive compounds extracted from different pears are reported as being protective against various human disorders including ageing, cancer, cardiovascular disease, nerve dysfunction, 
respiratory distress syndrome and diabetes [5]. Thus, the bioactive compound extracts from different pears, especially polyphenols, may contribute to human health.

Polyphenols are important plant-derived secondary metabolites, which include hydrolyzed tannin (acid ester polyphenols) and condensed tannin (flavanols polyphenols or proanthocyanins) [6]. Polyphenols consist of aromatic rings with attached hydroxyl groups, organic acids and acylated sugars. This unique structure endows polyphenols with high antioxidant activity which can directly or indirectly prevent the formation of free radicals [5]. The most abundant polyphenols in pears include flavan-3-ols, flavonols, phenolic acids, anthocyanins and hydroquinones [7]. The antioxidant potential of polyphenols in pears can be determined by several chemical assays each of which depend upon different mechanisms. These in vitro spectrophotometric-based assays include 2,2'-diphenyl-1-picrylhydrazyl (DPPH) free radical scavenging assay, ferric reducing antioxidant power (FRAP) assay, 2,2'-azinobis-(3-ethylbenzothiazoline-6-sulfonic acid) (ABTS) assay and total antioxidant capacity (TAC) [8].

In recent years, there has been increasing interest in the extraction of polyphenols from different plant materials. It is difficult to extract, separate, determine and identify a particular type of phenolic compounds from plant-materials due to their chemical and structural diversity. Liquid chromatography coupled with electrospray-ionization quadrupole time-of-flight mass spectrometry (LC-ESI-QTOF-MS/MS), is a new technique with higher sensitivity, which is purported to be the most effective method for the characterization and determination of both low and high molecule weight polyphenols [9]. Furthermore, high performance liquid chromatography (HPLC) is another useful tool that is used to quantify the targeted phenolic compounds in combination with different detectors, such as ultraviolet-visible (UV) and photodiode array detector (PDA) [10]. In the previous study, the phenolic compounds, which include quinic acid, flavan-3-ols, flavonols, flavones, hydroquinones, anthocyanins and their derivatives were characterized using both HPLC and LC-MS methods [1]. These results show that caffeic acid, monomeric catechins, polymeric procyanidins, isorhamnetin derivatives, chlorogenic acid and arbutin are the main phenolic compounds in pears [1].

Although a number of studies have identified and quantified the phenolic compounds in different pear varieties grown in different regions, only a few of them focus on the phenolic compounds in Australian grown pears, which include Packham's Triumph, Josephine de Malines, Beurre Bosc, Winter Nelis and Rico. Therefore, the objective of this study is to determine the total polyphenol content (TPC), total flavonoid content (TFC) and total tannin content (TTC) in Australian grown pears and measure the antioxidant activity by determining DPPH, ABTS radical-scavenging activity, FRAP and TAC. This study also characterized and identified the phenolic compounds from pears by LC-ESI-QTOF-MS/MS and quantified through HPLC-PDA.

\section{Materials and Methods}

\subsection{Chemicals and Reagents}

Most of the chemicals used for extraction and characterization were analytical grade and purchased from Sigma-Aldrich (Castle Hill, NSW, Australia). Folin and Ciocalteu's phenol reagent, gallic acid, L-ascorbic acid, vanillin, hexahydrate aluminum chloride, quercetin, catechin, 2,2'-diphenyl-1-picrylhy-drazyl (DPPH), 2,4,6-tripyridyl-s-triazine (TPTZ) and 3-ethylbenzothiazoline-6-sulphonic acid (ABTS) were bought from the SigmaAldrich (Castle Hill, NSW, Australia). The chemical reagent and reference standard for HPLC, including gallic acid, protocatechuic acid, $p$-hydroxybenzoic acid, chlorogenic acid, caffeic acid, catechin, epicatechin, epicatechin gallate, quercetin and kaempferol were produced by Sigma-Aldrich (Castle Hill, NSW, Australia). Sodium carbonate anhydrous were purchased from Chem-Supply Pty Ltd. (Adelaide, SA, Australia) and 98\% sulfuric acid were bought from RCI Labscan (Rongmuang, Thailand). Methanol, acetonitrile, ferric chloride $\left(\mathrm{Fe}[\mathrm{III}] \mathrm{Cl}_{3} \bullet 6 \mathrm{H}_{2} \mathrm{O}\right)$, hydrated sodium acetate, hydrochloric acid and glacial acetic acid were purchased from Thermo Fisher Scientific Inc. (Scoresby, VIC, Australia). 


\subsection{Sample Preparation}

The fresh fruits of five Australian grown pear varieties, Rico, Packham's Triumph, Beurre Bosc, Winter Nelis and Josephine de Malines (Figure 1) grown in different region of Victoria were purchased from local markets in Melbourne, Victoria, Australia. A fully mature pear samples were harvested, stored at room temperature for 24-48 h for optimum ripening followed by transportation and distribution to the local retailers within 2-3 days using refrigerated trucks. Two to three kilogram samples of each variety were cleaned and peeled; the seeds were removed and pulp was blended using the $1.5 \mathrm{~L}$ blender (Russell Hobbs Classic, model DZ-1613, Melbourne, VIC, Australia). The pear pulps were kept at $-20{ }^{\circ} \mathrm{C}$ for $48 \mathrm{~h}$ and lyophilized at $-45^{\circ} \mathrm{C} / 50 \mathrm{MPa}$ by Dynavac engineering FD3 Freeze Drier (W.A., Australia) and Edwards RV12 oil sealed rotary vane pump (Bolton, UK) and the freeze dried powders were stored at $-20{ }^{\circ} \mathrm{C}$.

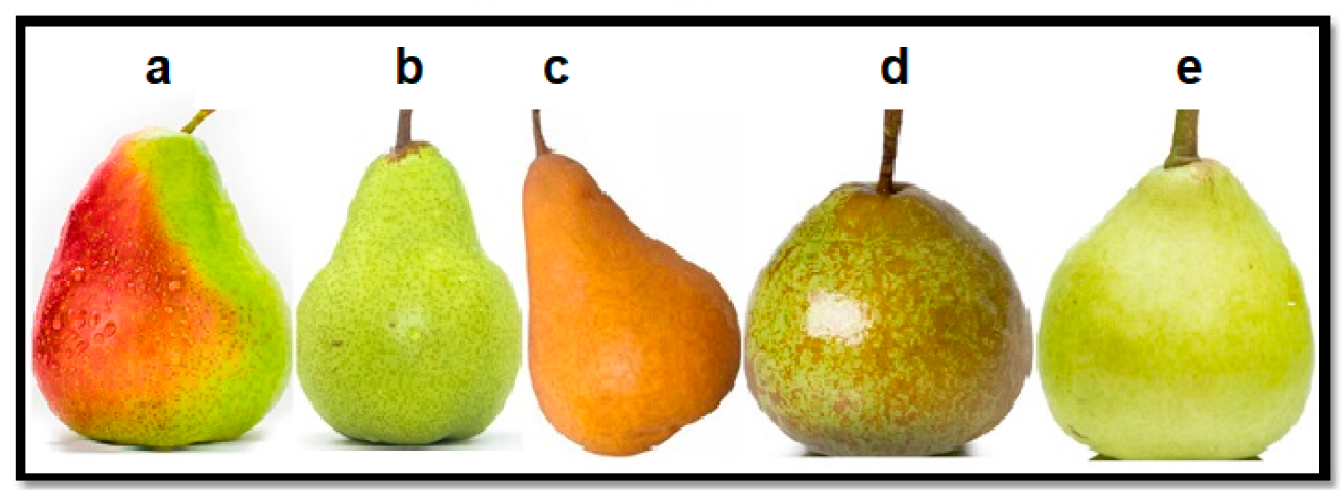

Figure 1. Australian grown pear varieties (a), Rico (b), Packham's Triumph (c), Beurre Bosc (d) Winter Nelis and (e) Josephine de Malines.

\subsection{Extraction of Phenolic Compounds}

The extracts were made by modifying the protocol of Peng et al. [10], $5 \mathrm{~g}$ of pear powder was mixed with $20 \mathrm{~mL} \mathrm{70 \%} \mathrm{ethanol} \mathrm{and} \mathrm{homogenized} \mathrm{with} \mathrm{the} \mathrm{IKA} \mathrm{Ultra-Turrax}{ }^{\circledR}$ T25 homogenizer (Rawang, Selangor, Malaysia) and subjected to shaking incubator (ZWYR240, Labwit, Ashwood, VIC, Australia) at $120 \mathrm{rpm}$ for $12 \mathrm{~h}\left(4^{\circ} \mathrm{C}\right)$. After incubation, the pear extracts were centrifuged with Hettich Refrigerated Centrifuge (ROTINA380R, Tuttlingen, Baden-Württemberg, Germany) at $1000 \mathrm{rpm}$ for $15 \mathrm{~min}$. The supernatants were collected and stored at $-20^{\circ} \mathrm{C}$ before further analysis.

\subsection{Estimation of Phenolic Compounds and Antioxidant Assay}

The TPC, TFC and TTC assays were conducted to estimate the polyphenols in the samples. For antioxidant activities, three different antioxidant assays, including DPPH, ABTS and FRAP assay were used, which are based on the method and parameter from Tang et al. [11]. The spectrophotometric data were collected on the Multiskan ${ }^{\circledR}$ Go microplate photometer (Thermo Fisher Scientific, Waltham, MA, USA).

\subsubsection{Determination of Total Phenolic Content (TPC)}

The TPC of pear samples was determined by the spectrophotometric method of Samsonowicz et al. [12] with some modification. The sample extracts $(25 \mu \mathrm{L})$, FolinCiocalteu reagent solution $(25 \mu \mathrm{L}, 1: 3$ diluted with water $)$ and Milli-Q water $(200 \mu \mathrm{L})$ were added in a 96-well plate (Costar, Corning, NY, USA). After incubation $\left(25^{\circ} \mathrm{C}, 5 \mathrm{~min}\right), 25 \mu \mathrm{L}$ $10 \%(w: w)$ sodium carbonate was added and followed by incubation in the dark for $60 \mathrm{~min}$. The absorbance was determined at $764 \mathrm{~nm}$ in a microplate reader (Thermo Fisher Scientific, Waltham, MA, USA). The quantification of each sample was based on the standard curve that was generated with $0-200 \mu \mathrm{g} / \mathrm{mL}$ gallic acid in ethanol. The result was expressed as $\mathrm{mg}$ of gallic acid equivalents per gram dry weight of sample (mg GAE/g of DW). 


\subsubsection{Determination of Total Flavonoid Content (TFC)}

The TFC of the pear sample was measured by modifying the aluminum chloride method of Stavrou et al. [13]. The sample extracts $(80 \mu \mathrm{L}), 2 \%$ aluminum chloride ( $80 \mu \mathrm{L}$, $w / v$, diluted with ethanol) and sodium acetate solution $(120 \mu \mathrm{L}, 50 \mathrm{~g} / \mathrm{L})$ were mixed in a 96-well plate and then incubated in the dark at room temperature for $60 \mathrm{~min}$. The absorbance was measured at $440 \mathrm{~nm}$ in a microplate reader. The calculation of TFC of each sample was based on the standard curve of quercetin $(0$ to $50 \mu \mathrm{g} / \mathrm{mL})$ and the result was expressed as $\mathrm{mg}$ of quercetin equivalent per $\mathrm{g}(\mathrm{mg} \mathrm{QE} / \mathrm{g} \mathrm{DW})$ of dry weight.

\subsubsection{Determination of Total Tannin Content (TTC)}

The TTC of the pear samples was estimated by the method of Stavrou et al. [13] with some modification. The sample extracts ( $25 \mu \mathrm{L}, 1: 50$ diluted with methanol), $4 \%$ vanillin solution $(150 \mu \mathrm{L}$, diluted with methanol) and $32 \%$ sulfuric acid $(25 \mu \mathrm{L})$ were mixed in a 96-well plate and followed by incubation at $25{ }^{\circ} \mathrm{C}$ for $15 \mathrm{~min}$. The absorbance was measured at $500 \mathrm{~nm}$ against a blank in a microplate reader. The calculation of results was based on the standard curve of catechin solution (concentration from $0-1000 \mu \mathrm{g} / \mathrm{mL}$ ). The result was expressed as $\mathrm{mg}$ of catechin equivalent per $\mathrm{g}(\mathrm{mg} \mathrm{CE} / \mathrm{g} \mathrm{DW})$ of dry weight.

\subsubsection{2,2'-Diphenyl-1-picrylhydrazyl (DPPH) Assay}

The radical scavenging activity of pears was determined by DPPH assay method with some modification of Sogi et al. [14]. Sample extract $(40 \mu \mathrm{L})$ was mixed with 0.1 M DPPH radical methanol solution $(260 \mu \mathrm{L})$ in a 96-well plate, then incubated at $25^{\circ} \mathrm{C}$ for $30 \mathrm{~min}$. The absorbance was measured at $517 \mathrm{~nm}$ in a microplate reader. The standard curve was generated with different concentration of ascorbic acid $(0$ to $50 \mu \mathrm{g} / \mathrm{mL})$. The result was expressed as mg ascorbic acid equivalents per g of dry weights (mg AAE/g DW).

\subsubsection{Ferric Reducing Antioxidant Power (FRAP) Assay}

The reducing capacity of the pear samples was determined based on the method of Sogi et al. [14] with some modification. This method involved the determination of the ability to reduce $\mathrm{Fe}^{3+}$ in the $\mathrm{Fe}^{3+}$-TPTZ complex (ferric-2,4,6-tripyridyl-s-Triazine) into $\mathrm{Fe}^{2+}$-TPTZ. Sodium acetate solution $(300 \mathrm{mM})$, TPTZ solution $(10 \mathrm{mM})$ and ferric chloride $(20 \mathrm{mM})$ was mixed in a ratio of 10:1:1 $(v / v / v)$ to freshly made FRAP reagent. Then, sample extract $(20 \mu \mathrm{L})$ and prepared FRAP dye solution $(280 \mu \mathrm{L})$ were added to a 96-well plate and followed by incubation at $37^{\circ} \mathrm{C}$ for $10 \mathrm{~min}$. The absorbance was measured at $593 \mathrm{~nm}$ in microplate reader. The standard curve was generated with ascorbic acids range from 0 to $50 \mu \mathrm{g} / \mathrm{mL}$. The results were expressed as $\mathrm{mg}$ of ascorbic acid equivalents per $\mathrm{g}(\mathrm{mg}$ $\mathrm{AAE} / \mathrm{g} \mathrm{DW}$ ) of dry weight.

\subsubsection{2,2'-Azino-bis-3-ethylbenzothiazoline-6-sulfonic Acid (ABTS) Assay}

The free radical scavenging capacity of the pear samples was determined by $\mathrm{ABTS}^{+}$ radical cation decolorization assay with some modification of Sogi et al. [14]. $7 \mathrm{mmol} / \mathrm{L}$ of ABTS solution ( $5 \mathrm{~mL}$ ) and $140 \mathrm{mM}$ potassium persulfate decolorization solution were mixed to make $\mathrm{ABTS}^{+}$stock solutions. The mixture was incubated in the dark for $16 \mathrm{~h}$ (room temperature) and then $\mathrm{ABTS}^{+}$stock solution was diluted with ethanol to obtain an initial absorbance of 0.700 at $734 \mathrm{~nm}$. Afterwards, the pear sample extract $(10 \mu \mathrm{L})$ was mixed with the prepared diluent in 96-well plate and followed by incubation in the dark at room temperature for $6 \mathrm{~min}$. The absorbance was measured at $734 \mathrm{~nm}$ in microplate reader. The standard curve was generated with ascorbic acid with concentration ranging from 0 to $150 \mu \mathrm{g} / \mathrm{mL}$. The ABTS value was expressed as $\mathrm{mg}$ of ascorbic acid equivalents per $\mathrm{g}$ (mg $\mathrm{AAE} / \mathrm{g}$ DW) of dry weight. 


\subsubsection{Total Antioxidant Capacity (TAC)}

The TAC was determined by following the modified protocol of Subbiah et al. [15]. First, $0.6 \mathrm{M} \mathrm{H}_{2} \mathrm{SO}_{4}, 0.028 \mathrm{M}$ sodium phosphate and $0.004 \mathrm{M}$ ammonium molybdate were mixed to make the phosphomolybdate reagent. Next, the pear sample extract $(40 \mu \mathrm{L})$ and phosphomolybdate reagent $(260 \mu \mathrm{L})$ were mixed in 96-well plate and followed by incubation at $95^{\circ} \mathrm{C}$ for $10 \mathrm{~min}$. The absorbance was determined at $695 \mathrm{~nm}$. The standard curve was generated with ascorbic acid with concentration ranging from $0-200 \mu \mathrm{g} / \mathrm{mL}$. The TAC values were expressed as mg of ascorbic acid equivalents per $\mathrm{g}$ (mg AAE/g DW) of dry weight.

\subsection{Characterization of Phenolic Compounds by LC-ESI-QTOF-MS/MS Analysis}

Characterization of phenolic compounds in pears was carried out using the method of Suleria et al. [16]. An Agilent 1200 series HPLC (Agilent Technologies, Santa Clara, CA, USA) equipped with Agilent 6520 I Accurate-Mass Q-TOF LC-MS/MS (Agilent Technologies, Santa Clara, CA, USA) was used in the characterization and identification of phenolic compounds in pears. The separation of different phenolic compounds was conducted in Synergi Hydro-RP $80 \AA$ LC reverse phase with $250 \mathrm{~mm} \times 4.6 \mathrm{~mm}$ internal diameter and $4 \mu \mathrm{m}$ particle size (Phenomenex, Torrance, CA, USA). The mobile phase A, which consists of water/acetic acid solution $(98: 2, v / v)$, was combined with mobile phase B, which consists of acetonitrile/water/acetic acid solution (50:49.5:0.5, $v / v / v)$ to form the binary solvent system at the flow rate of $0.8 \mathrm{~mL} / \mathrm{min}$ with a sample injection volume $6 \mu \mathrm{L}$. The gradient elution lasted for $85 \mathrm{~min}$ with the following conditions: $0 \mathrm{~min}, 90 \% \mathrm{~A}$ and $10 \% \mathrm{~B} ; 20 \mathrm{~min}$, $75 \% \mathrm{~A}$ and $25 \% \mathrm{~B} ; 30 \mathrm{~min}, 65 \% \mathrm{~A}$ and $35 \% \mathrm{~B} ; 40 \mathrm{~min}, 60 \% \mathrm{~A}$ and $40 \% \mathrm{~B} ; 70 \mathrm{~min}, 45 \%$ $\mathrm{A}$ and $55 \% \mathrm{~B} ; 75 \mathrm{~min}, 20 \% \mathrm{~A}$ and $80 \% \mathrm{~B} ; 77-79 \mathrm{~min}, 0 \% \mathrm{~A}$ and $100 \% \mathrm{~B} ; 82-85 \mathrm{~min}, 90 \%$ $A$ and $10 \%$ B. Both the positive and negative ion mode were used in peak identification with capillary at $3.5 \mathrm{LV}$ and nozzle voltage at $500 \mathrm{~V}$. The parameters of mass spectrometry were set as follows: for nitrogen gas, the pressure was set at 45 psi with the flow rate of $5 \mathrm{~L} / \mathrm{min}$ at $300^{\circ} \mathrm{C}$; for sheath gas, the flow rate and temperature were set at $11 \mathrm{~L} / \mathrm{min}$ and $250{ }^{\circ} \mathrm{C}$. The range of mass spectra was set at $m / z 50-1300$. Further, MS/MS analyses were carried out in automatic mode with collision energy $(10,15$ and $30 \mathrm{eV})$ for fragmentation. Data collection and processing was conducted using MassHunter (Qualitative Analysis, version B.03.01, Agilent).

\subsection{HPLC-PDA Analysis}

The quantification of targeted phenolic compounds in pears was measured by the method of Zhong et al. [17] and performed by Agilent 1200 series HPLC (Agilent Technologies, Santa Clara, CA, USA) equipped with a photodiode array (PDA) detector. The column and conditions in HPLC-PDA analysis were similar to LC-MS/MS analysis, while the sample injection volume was changed to $20 \mu \mathrm{L}$. The phenolic compounds were determined at three different wavelengths, including $280 \mathrm{~nm}, 320 \mathrm{~nm}$ and $370 \mathrm{~nm}$. The quantification of the concentration of individual polyphenols was based on the calibration standard curve and the result was expressed as $\mathrm{mg} / \mathrm{g}$ of sample. Data collection and processing was performed using Agilent LC-ESI-QTOF-MS/MS MassHunter (Qualitative Analysis, version B.03.01, Agilent).

\subsection{Statistical Analysis}

Three parallel experiments were conducted in each test and the data are expressed as mean \pm standard deviation. Statistical analysis was performed by using Minitab ${ }^{\circledR}$ 18 Statistical software (Minitab Inc., State College, PA, USA). One-way analysis of variance (ANOVA) followed by Tukey's honestly significant differences (HSD) multiple rank test was carried out to test whether there was a significant difference between the antioxidant activities and polyphenol content of each sample at $p<0.05$. 


\section{Results and Discussion}

\subsection{Phenolic Compound Estimation (TPC, TFC and TTC)}

Previously, several studies have estimated the phenolic content of different pear varieties by determining different parameters. In this study, the phenolic content in pears were determined by the TPC, TFC and TTC and the results were expressed as mg of gallic acid equivalents per gram dry weight of sample (mg GAE/g of DW) mentioned in Table 1.

Table 1. Antioxidant potentials of five Australian grown pear varieties.

\begin{tabular}{cccccc}
\hline Antioxidant Assays & Beurre Bosc & $\begin{array}{c}\text { Josephinede } \\
\text { Malines }\end{array}$ & $\begin{array}{c}\text { Packham's } \\
\text { Triumph }\end{array}$ & Winter Nelis & Rico \\
\hline TPC (mg GAE/g) & $3.14 \pm 0.02^{\mathrm{a}}$ & $2.75 \pm 0.03^{\mathrm{b}}$ & $2.19 \pm 0.06^{\mathrm{d}}$ & $1.89 \pm 0.03^{\mathrm{e}}$ & $2.45 \pm 0.09^{\mathrm{c}}$ \\
TFC (mg QE/g) & $1.04 \pm 0.07^{\mathrm{b}}$ & $1.53 \pm 0.09^{\mathrm{a}}$ & $0.94 \pm 0.07^{\mathrm{c}}$ & $0.57 \pm 0.05^{\mathrm{e}}$ & $0.74 \pm 0.07^{\mathrm{d}}$ \\
TTC (mg CE/g) & $1.43 \pm 0.04^{\mathrm{a}}$ & $1.01 \pm 0.04^{\mathrm{c}}$ & $0.81 \pm 0.03^{\mathrm{d}}$ & $0.72 \pm 0.09^{\mathrm{d}}$ & $1.10 \pm 0.03^{\mathrm{b}}$ \\
DPPH (mg AAE/g) & $5.72 \pm 0.11^{\mathrm{a}}$ & $4.78 \pm 0.06^{\mathrm{b}}$ & $4.12 \pm 0.09^{\mathrm{c}}$ & $3.25 \pm 0.03^{\mathrm{d}}$ & $4.72^{\mathrm{a}} \pm 0.06^{\mathrm{b}}$ \\
FRAP (mg AAE/g) & $3.93 \pm 0.04^{\mathrm{b}}$ & $4.37 \pm 0.04^{\mathrm{a}}$ & $3.14 \pm 0.07^{\mathrm{c}}$ & $2.15 \pm 0.07^{\mathrm{e}}$ & $2.94^{\mathrm{a}} \pm 0.01^{\mathrm{d}}$ \\
ABTS (mg AAE/g) & $4.41 \pm 0.07^{\mathrm{a}}$ & $4.44 \pm 0.01^{\mathrm{a}}$ & $3.97 \pm 0.10^{\mathrm{b}}$ & $2.83 \pm 0.06^{\mathrm{d}}$ & $3.19^{\mathrm{a}} \pm 0.04^{\mathrm{c}}$ \\
TAC (mg AAE/g) & $3.92 \pm 0.04^{\mathrm{c}}$ & $5.29 \pm 0.09^{\mathrm{a}}$ & $4.85 \pm 0.03^{\mathrm{b}}$ & $3.94 \pm 0.01^{\mathrm{c}}$ & $2.87^{\mathrm{a}} \pm 0.09^{\mathrm{d}}$ \\
\hline
\end{tabular}

$\mathrm{a}, \mathrm{b}, \mathrm{c}, \mathrm{d}, \mathrm{e}$ indicate the means in a row with significant difference $(p<0.05)$ using a one-way analysis of variance (ANOVA) and Tukey's test. TPC, total phenolic content; TFC, total flavonoid content; TTC, total tannin content; DPPH, 2,2'-diphenyl-1-picrylhydrazyl assay; FRAP, ferric reducing antioxidant power assay; ABTS, 2,2'-azino-bis-3-ethylbenzothiazoline-6-sulfonic acid assay; TAC, total antioxidant capacity; $\mathrm{GAE}$, gallic acid equivalents; $\mathrm{QE}$, quercetin equivalents; $\mathrm{CE}$, catechin equivalents; $\mathrm{AAE}$, ascorbic acid equivalents.

The TPC of Beurre Bosc pulp (3.14 $\pm 0.02 \mathrm{mg}$ GAE/g) was higher than Josephine de Malines, Packham's Triumph, Winter Nelis and Rico. Our results were slightly higher than Turkish grown pear varieties including Egirsah, Gugum, Deveci, Kizil and Banda, also extracted in methanol with different concentration (1.75 $\pm 0.13 \mathrm{mg}$ GAE/g) [18]. The difference in the sample variety, growing region, sample extraction techniques, type of solvent, solute to solvent ratio may contribute to the difference in results. However, Manzoor et al. [19] reported the total phenolic content of Nakh and Naspati pear were in range of our study.

Regarding the TFC, the Josephine de Malines (1.53 $\pm 0.09 \mathrm{mg}$ QE/g DW) had higher flavonoid content than Beurre Bosc, Packham's Triumph, Winter Nelis and Rico. The results were similar to the TFC values (ranging from 0.3 to $6 \mathrm{mg} Q E / g$ ) reported by Azzini et al. [20] and Li et al. [21]. Rawat et al. [22] also determined the higher total flavonoid content in one of the southern Asia grown pear varieties (Pyrus pashia) by aluminum chloride colorimetric assay and extracted with different solvent and solvent to solute ratio. Previously, Patricia et al. [23] also confirmed that the total flavonoid content of pears can be varied significantly using different extraction solvents including $n$-hexane, ethyl acetate, ethanol and methanol.

The Beurre Bosc pear has the highest TTC value $(1.43 \pm 0.04 \mathrm{mg}$ CE/g DW) as compared to other pear varieties (Table 1). Previously, only a few studies have focused on the total tannin content of pears. Ma et al. [24] have detected slightly higher total tannin content in one of the apple-shaped pear varieties (Pyrus pyrifolia) using another method of $n$-BuOH-HCl-Fe-III. In addition, Velmurugan and Bhargava [25] had also reported difference in total tannin content of European grown pear varieties extracted with different solvents (chloroform, aqueous, ethyl acetate and ethanol) and using another method of Folin-Denis. However, due to the difference in the detection methods and calibrators, it is difficult to be compare these findings with the TTC value in our experiment. This is why we have expanded our suite of antioxidant assays to better characterize the antioxidant potential of Australian grown pear samples. 


\subsection{Antioxidant Activity (DPPH, FRAP, ABTS and TAC)}

The antioxidant activities of pears were determined by DPPH, FRAP, ABTS and TAC assays. In current research, different types of antioxidant assays were performed, involved different mechanisms, to understand overall and true antioxidant potential of pear fruit. The results of DPPH test ranged from $3.25 \pm 0.03$ to $5.72 \pm 0.1 \mathrm{mg} \mathrm{AAE} / \mathrm{g}$, with statistically significant differences between pear varieties except for Josephine de Malines and Rico (Table 1). The Beurre Bosc had the highest DPPH free radical scavenging capacity followed by Josephine de Malines, Rico, Packham's Triumph and Winter Nelis. In the previous study, Nomura et al. [26] measured the DPPH radical scavenging activity of 29 varieties of Japanese and European grown pears, some of their pear varieties had the similar DPPH free radical scavenging activity with our Australian grown pear varieties. In addition, Galvis Sánchez et al. [27] determined the DPPH free radical scavenging capacity of six Chile grown European pear varieties while their DPPH values were slightly lower than our study. The difference in pear varieties, extraction solvent, growing region, condition and harvesting season may contribute to the difference of results.

For the FRAP assay, all the varieties show significant differences from each other. Josephine de Malines had the highest FRAP activity which is $4.37 \pm 0.04 \mathrm{mg}$ AAE/g, followed by Beurre Bosc, Packham's Triumph, Rico and Winter Nelis. Previously, the total antioxidant activity of two Greece grown pears varieties (Naoussa and Vergina) measured by FRAP method ranged from $1.41 \mathrm{mg}$ AAE/g to $1.93 \mathrm{mg}$ AAE/g which is slightly lower than our FRAP values [28,29]. Gu et al. [30] also reported the slightly lower antioxidant capacity of European pears extracted with different solvent to solute ratio. However, Jamuna et al. [31] detected the antioxidant activity of an Indian grown pear variety (Pyrus communis) by FRAP assay and the result (3.00 $\mathrm{mg} \mathrm{AAE} / \mathrm{g}$ ) was consistent with our Australian grown pear varieties.

Based on the ABTS assay, Josephine de Malines and Beurre Bosc were not different, but they were significantly higher than the other varieties. Thus, Josephine de Malines and Beurre Bosc have the highest ABTS value $(4.44 \pm 0.01$ and $4.41 \pm 0.07 \mathrm{mg} \mathrm{AAE} / \mathrm{g}$, respectively) followed by Packham's Triumph, Rico and Winter Nelis (Table 1). In the previous study, Batista et al. [32] reported that the ABTS values of different Portugal grown pear varieties including S. Bartolomeu and Amêndoa pears and the results were slightly lower than our investigation. Erbil et al. [18] also measured the ABTS free radical scavenging activity of five different Turkish grown pear varieties (Egirsah, Gugum, Deveci, Kizil and Banda) and found that there was a significant difference of the ABTS free radical scavenging capacity between different pear varieties grown in the same region.

When antioxidant activity was measured using the TAC assay there were significant differences between all varieties except Beurre Bosc and Winter Nelis. Josephine de Malines had the higher TAC value (5.29 $\pm 0.09 \mathrm{mg}$ AAE/g), followed by Packham's Triumph, Winter Nelis, Beurre Bosc and Rico. Previously, Jamuna et al. [33] reported the TAC capacity (1.45 mg AAE/g) of Indian grown pear variety (Pyrus communis) extracted using chloroform-water which was lower than our values. The difference in pear varieties, growing region, extraction solvent, solute to solvent ratio and harvesting season may contribute to the difference of results.

In the present study, Beurre Bosc had the highest antioxidant capacity when measured using TPC, TTC, DPPH, FRAP and ABTS assays while Winter Nelis was consistently low TAC for all assays. Thus, the antioxidant capacity of pears can be associated with their polyphenol content. Different varieties, genotypes and agronomy of pears influence the polyphenol content and thereby influence their antioxidant activity.

\subsection{Correlation among Different Antioxidant Variables}

The correlations between TPC, TFC, TTC and antioxidant assays (DPPH, FRAP, ABTS and TAC) were performed by Pearson's correlation test by Graphpad Prism 8 (Table 2). There was a significant positive correlation between TPC and TTC $(r=0.93, p \leq 0.05)$ and a highly significant positive correlation between TPC and DPPH value $(r=0.97, p \leq 0.01)$. 
This result is consistent with the research reported by Kolniak-Ostek [1]. The TPC estimate the phenolic content in samples and DPPH scavenging capacity measures the antioxidant activities, therefore the phenolic content in pears mainly contribute to the antioxidant activities of sample.

Table 2. Pearson's correlation between antioxidant capacity by different antioxidant assays.

\begin{tabular}{ccccccc}
\hline Variables & TPC & TFC & TTC & DPPH & FRAP & ABTS \\
\hline TFC & 0.634 & & & & & \\
TTC & $0.934^{*}$ & 0.322 & & & \\
DPPH & $0.973^{* *}$ & 0.529 & $0.958^{* *}$ & & \\
FRAP & 0.854 & $0.939^{* *}$ & 0.619 & 0.785 & & \\
ABTS & 0.791 & $0.869 *$ & 0.555 & 0.731 & $0.940^{* *}$ & \\
TAC & 0.063 & 0.716 & -0.279 & -0.072 & 0.510 & 0.621 \\
${ }^{* *}$ Significant correlation with $p \leq 0.01 ;{ }^{*}$ Significant correlation with $p \leq 0.05$. & &
\end{tabular}

Furthermore, TFC is strongly correlated with FRAP value with Pearson's correlation coefficient $(r=0.93, p \leq 0.01)$. Previously, the strong positive correlation between TFC and FRAP value of pear was also observed by Azzini et al. [20] with $r=0.919$. FRAP measures the ability to reduce the $\mathrm{Fe}^{3+}$-TPTZ complex into $\mathrm{Fe}^{2+}-\mathrm{TPTZ}$, while TFC only determined the flavonoid content in samples. Thus, this correlation indicates that the antioxidant capacity is positively related to the presence of flavonoid compounds. Furthermore there was also a significant positive correlation between TFC and ABTS $(r=0.87, p \leq 0.05)$ which was similar to the findings of Floegel et al. [34]. However, Li et al. [21] also observed a strong correlation between DPPH and TFC which was not significant in this study. This may due to the flavonoid compounds have no obvious effect on DPPH free radical scavenging ability.

Apart from above, TTC displays a highly significant positive correlation with DPPH assay with $(r=0.96, p \leq 0.01)$ which was similar to the findings of Li et al. [21]. This strong correlation indicates that the tannin in pears were related to the DPPH free radical scavenging capacity. This may due to the molecular structure of tannin in pears can provide $\mathrm{H}$ to DPPH free radicals to form DPPH-H [21]. Additionally, the FRAP assay is highly correlated with ABTS assay in the present study $(r=0.94, p \leq 0.01)$ which was consistent with the findings of $\mathrm{Du}$ et al. [35] who also observed a strong positive correlation $(r=0.92)$ between TAC measured using the FRAP and ABTS methods. The strong correlations between TAC measured using ABTS and FRAP is expected because both methods are relying on the single electron transfer principle. For further elucidation of the sources of the TAC activity, LC-ESI-QTOF-MS/MS and HPLC-PDA were used for identification, characterization and quantification of phenolic compounds in different pear samples.

\subsection{LC-MS Analysis}

In the present work, the quantitative analysis of the phenolic compounds in five varieties of pears was carried out by LC-ESI-QTOF-MS/MS analysis in both positive and negative ionization modes. The phenolic compounds were tentatively identified and characterized and based on the $\mathrm{m} / \mathrm{z}$ value from MS spectra in both negative and positive modes $\left([\mathrm{M}-\mathrm{H}]^{-} /[\mathrm{M}+\mathrm{H}]^{+}\right)$(Supplementary data: Figures S1 and S2). The data analysis was carried out by using Agilent LC/MS Mass Hunter Qualitative software and Personal Compound Database and Library (PCDL). Only the compounds with a PCDL score higher than 80 and the mass error less than $\pm 5 \mathrm{ppm}$ were selected for characterization and verification purposes. A total of 73 phenolic compounds were identified in different pear varieties, which include phenolic acids (30), flavonoids (29), stilbenes (1) and other polyphenols (13) mentioned in Table 3. 


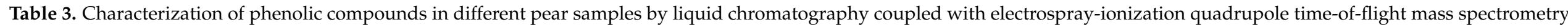
(LC-ESI-QTOF-MS/MS).

\begin{tabular}{|c|c|c|c|c|c|c|c|c|c|c|}
\hline No. & $\begin{array}{l}\text { Molecular } \\
\text { Formula }\end{array}$ & Proposed Compounds & RT (min) & $\begin{array}{l}\text { Ionization } \\
\left(\mathrm{ESI}^{+} / \mathrm{ESI}^{-}\right)\end{array}$ & $\begin{array}{c}\text { Molecular } \\
\text { Weight }\end{array}$ & $\begin{array}{l}\text { Theoretical } \\
(\mathrm{m} / \mathrm{z})\end{array}$ & $\begin{array}{l}\text { Observed } \\
\quad(\mathrm{m} / \mathrm{z})\end{array}$ & Error (ppm) & $\begin{array}{c}\mathrm{MS}^{2} \\
\text { Production }\end{array}$ & Pears \\
\hline \multicolumn{11}{|c|}{$\begin{array}{l}\text { Phenolic acid } \\
\text { Hydroxybenzoic Acids }\end{array}$} \\
\hline 1 & $\mathrm{C}_{8} \mathrm{H}_{8} \mathrm{O}_{7} \mathrm{~S}$ & Vanillic acid 4-sulfate & 5.122 & {$[\mathrm{M}-\mathrm{H}]^{-}$} & 247.9991 & 246.9918 & 246.9915 & -1.2 & 167 & BB \\
\hline 2 & $\mathrm{C}_{13} \mathrm{H}_{16} \mathrm{O}_{10}$ & Gallic acid 4-O-glucoside & 6.731 & {$[\mathrm{M}-\mathrm{H}]^{-}$} & 332.0743 & 331.067 & 331.0675 & 1.5 & 169,125 & ${ }^{*} \mathrm{RI}, \mathrm{BB}, \mathrm{JM}$ \\
\hline 3 & $\mathrm{C}_{7} \mathrm{H}_{6} \mathrm{O}_{5}$ & Gallic acid & 6.878 & {$[\mathrm{M}-\mathrm{H}]^{-}$} & 170.0215 & 169.0142 & 169.0145 & 1.8 & 125 & BB \\
\hline 4 & $\mathrm{C}_{13} \mathrm{H}_{16} \mathrm{O}_{9}$ & Protocatechuic acid 4-O-glucoside & 7.524 & {$[\mathrm{M}-\mathrm{H}]^{-}$} & 316.0794 & 315.0721 & 315.0718 & -1.0 & 153 & ${ }^{*} \mathrm{BB}, \mathrm{RI}, \mathrm{JM}, \mathrm{PT}$ \\
\hline 5 & $\mathrm{C}_{7} \mathrm{H}_{6} \mathrm{O}_{3}$ & 2-Hydroxybenzoic acid & 11.185 & {$[\mathrm{M}-\mathrm{H}]^{-}$} & 138.0317 & 137.0244 & 137.025 & 4.4 & 93 & * BB, JM, RI, PT \\
\hline 6 & $\mathrm{C}_{13} \mathrm{H}_{16} \mathrm{O}_{8}$ & 4-Hydroxybenzoic acid 4-O-glucoside & 11.218 & {$[\mathrm{M}-\mathrm{H}]^{-}$} & 300.0845 & 299.0772 & 299.0759 & -4.3 & 255,137 & ${ }^{*} \mathrm{BB}, \mathrm{WN}$ \\
\hline 7 & $\mathrm{C}_{14} \mathrm{H}_{10} \mathrm{O}_{9}$ & Gallic acid 3-O-gallate & 17.066 & {$[\mathrm{M}-\mathrm{H}]^{-}$} & 322.0325 & 321.0252 & 321.0239 & -4.0 & 169 & BB \\
\hline \multicolumn{11}{|c|}{ Hydroxycinnamic Acids } \\
\hline 9 & $\mathrm{C}_{9} \mathrm{H}_{8} \mathrm{O}_{3}$ & $m$-Coumaric acid & 5.207 & {$[\mathrm{M}-\mathrm{H}]^{-}$} & 164.0473 & 163.04 & 163.0397 & -1.8 & 119 & ${ }^{*} \mathrm{RI}, \mathrm{JM}, \mathrm{PT}$ \\
\hline 10 & $\mathrm{C}_{9} \mathrm{H}_{8} \mathrm{O}_{2}$ & Cinnamic acid & 9.219 & ${ }^{* *}[\mathrm{M}-\mathrm{H}]^{-}$ & 148.0524 & 147.0451 & 147.0461 & 4.8 & 103 & ${ }^{*} \mathrm{WN}, \mathrm{RI}, \mathrm{PT}, \mathrm{BB}$ \\
\hline 11 & $\mathrm{C}_{14} \mathrm{H}_{14} \mathrm{O}_{9}$ & Feruloyl tartaric acid & 10.506 & {$[\mathrm{M}-\mathrm{H}]^{-}$} & 326.0638 & 325.0565 & 325.0567 & 0.6 & 193,149 & $\mathrm{BB}$ \\
\hline 12 & $\mathrm{C}_{9} \mathrm{H}_{8} \mathrm{O}_{4}$ & Caffeic acid & 12.932 & ${ }^{* *}[\mathrm{M}-\mathrm{H}]^{-}$ & 180.0423 & 179.035 & 179.0346 & -2.2 & 143,133 & * JM, BB, RI \\
\hline 13 & $\mathrm{C}_{15} \mathrm{H}_{16} \mathrm{O}_{10}$ & Caffeic acid 3-O-glucuronide & 13.308 & {$[\mathrm{M}-\mathrm{H}]^{-}$} & 356.0743 & 355.067 & 355.0672 & 0.6 & 179 & RI \\
\hline 14 & $\mathrm{C}_{15} \mathrm{H}_{18} \mathrm{O}_{8}$ & $p$-Coumaric acid 4-O-glucoside & 14.962 & {$[\mathrm{M}-\mathrm{H}]^{-}$} & 326.1002 & 325.0929 & 325.0911 & -5.5 & 163 & BB \\
\hline 15 & $\mathrm{C}_{15} \mathrm{H}_{18} \mathrm{O}_{9}$ & Caffeoyl glucose & 19.343 & {$[\mathrm{M}-\mathrm{H}]^{-}$} & 342.0951 & 341.0878 & 341.0865 & -3.8 & 179,161 & * JM, PT \\
\hline 16 & $\mathrm{C}_{16} \mathrm{H}_{18} \mathrm{O}_{9}$ & 3-Caffeoylquinic acid & 24.793 & {$[\mathrm{M}-\mathrm{H}]^{-}$} & 354.0951 & 353.0878 & 353.0865 & -3.7 & $253,190,144$ & $\mathrm{JM}$ \\
\hline 17 & $\mathrm{C}_{16} \mathrm{H}_{18} \mathrm{O}_{10}$ & Ferulic acid 4-O-glucuronide & 26.748 & {$[\mathrm{M}-\mathrm{H}]^{-}$} & 370.09 & 369.0827 & 369.0838 & 3.0 & 193 & $\mathrm{JM}$ \\
\hline 20 & $\mathrm{C}_{17} \mathrm{H}_{20} \mathrm{O}_{9}$ & 3-Feruloylquinic acid & 29.432 & ${ }^{* *}[\mathrm{M}-\mathrm{H}]^{-}$ & 368.1107 & 367.1034 & 367.1028 & -1.6 & $\begin{array}{c}298,288,192 \\
191\end{array}$ & * JM, BB, WN \\
\hline 21 & $\mathrm{C}_{16} \mathrm{H}_{20} \mathrm{O}_{9}$ & Ferulic acid 4-O-glucoside & 33.867 & {$[\mathrm{M}-\mathrm{H}]^{-}$} & 356.1107 & 355.1034 & 355.1039 & 1.4 & $\begin{array}{c}193,178,149 \\
134\end{array}$ & RI \\
\hline 22 & $\mathrm{C}_{10} \mathrm{H}_{10} \mathrm{O}_{4}$ & Ferulic acid & 38.378 & {$[\mathrm{M}-\mathrm{H}]^{-}$} & 194.0579 & 193.0506 & 193.0499 & -3.6 & $178,149,134$ & $\mathrm{JM}$ \\
\hline 23 & $\mathrm{C}_{18} \mathrm{H}_{16} \mathrm{O}_{8}$ & Rosmarinic acid & 39.746 & {$[\mathrm{M}-\mathrm{H}]^{-}$} & 360.0845 & 359.0772 & 359.0773 & 0.3 & 179 & BB \\
\hline 24 & $\mathrm{C}_{25} \mathrm{H}_{24} \mathrm{O}_{12}$ & 1,5-Dicaffeoylquinic acid & 45.17 & {$[\mathrm{M}-\mathrm{H}]^{-}$} & 516.1268 & 515.1195 & 515.1176 & -3.7 & $\begin{array}{c}353,335,191 \\
179\end{array}$ & $\mathrm{JM}$ \\
\hline \multirow{2}{*}{\multicolumn{11}{|c|}{ Hydroxyphenylacetic Acids }} \\
\hline & & & & & & & & & & \\
\hline 26 & $\mathrm{C}_{8} \mathrm{H}_{8} \mathrm{O}_{4}$ & 3,4-Dihydroxyphenylacetic acid & 10.011 & {$[\mathrm{M}-\mathrm{H}]^{-}$} & 168.0423 & 167.035 & 167.0349 & -0.6 & 149,123 & ${ }^{*} \mathrm{RI}, \mathrm{BB}, \mathrm{WN}, \mathrm{JM}$ \\
\hline 27 & $\mathrm{C}_{8} \mathrm{H}_{8} \mathrm{O}_{3}$ & 2-Hydroxy-2-phenylacetic acid & 10.821 & {$[\mathrm{M}-\mathrm{H}]^{-}$} & 152.0473 & 151.04 & 151.0405 & 3.3 & 136,92 & BB \\
\hline
\end{tabular}


Table 3. Cont.

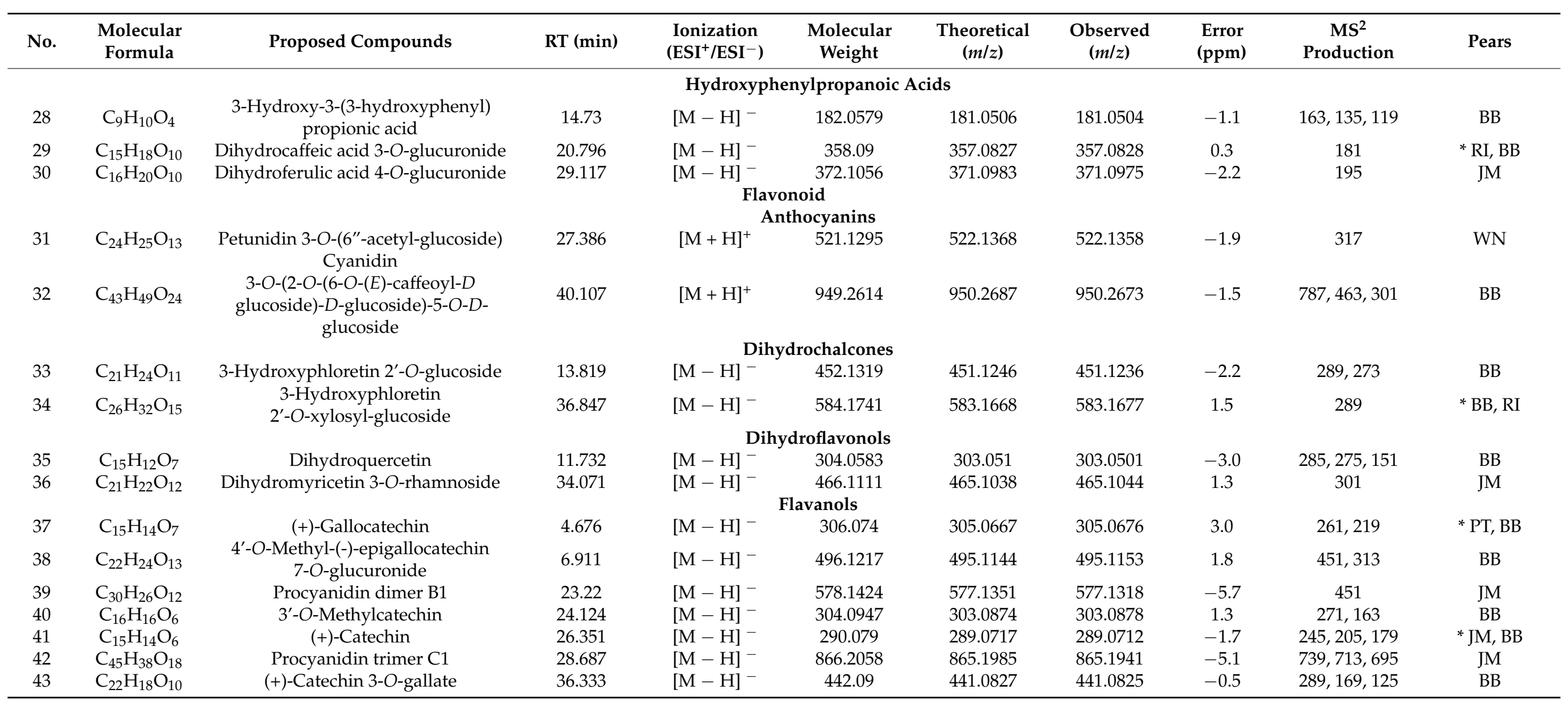


Table 3. Cont.

\begin{tabular}{|c|c|c|c|c|c|c|c|c|c|c|}
\hline No. & $\begin{array}{l}\text { Molecular } \\
\text { Formula }\end{array}$ & Proposed Compounds & RT (min) & $\begin{array}{l}\text { Ionization } \\
\left(\mathrm{ESI}^{+} / \mathrm{ESI}^{-}\right)\end{array}$ & $\begin{array}{l}\text { Molecular } \\
\text { Weight }\end{array}$ & $\begin{array}{l}\text { Theoretical } \\
(\mathrm{m} / \mathrm{z})\end{array}$ & $\begin{array}{l}\text { Observed } \\
\quad(\mathrm{m} / \mathrm{z})\end{array}$ & $\begin{array}{r}\text { Error } \\
(\mathrm{ppm})\end{array}$ & $\begin{array}{c}\text { MS }^{2} \\
\text { Production }\end{array}$ & Pears \\
\hline & \multicolumn{10}{|c|}{ Flavanones } \\
\hline 44 & $\mathrm{C}_{28} \mathrm{H}_{30} \mathrm{O}_{18}$ & Hesperetin 3',7-O-diglucuronide & 9.315 & {$[\mathrm{M}-\mathrm{H}]^{-}$} & 654.1432 & 653.1359 & 653.1362 & 0.5 & $\begin{array}{l}477,301,286, \\
242\end{array}$ & RI \\
\hline 45 & $\mathrm{C}_{22} \mathrm{H}_{22} \mathrm{O}_{12}$ & Hesperetin 3'-O-glucuronide & 47.368 & {$[\mathrm{M}-\mathrm{H}]^{-}$} & 478.1111 & 477.1038 & 477.1022 & -3.4 & $\begin{array}{l}301,286,257 \\
242\end{array}$ & PT \\
\hline $\begin{array}{l}46 \\
47\end{array}$ & $\begin{array}{l}\mathrm{C}_{27} \mathrm{H}_{30} \mathrm{O}_{14} \\
\mathrm{C}_{27} \mathrm{H}_{30} \mathrm{O}_{15}\end{array}$ & $\begin{array}{l}\text { Rhoifolin } \\
\text { Apigenin 6,8-di-C-glucoside }\end{array}$ & $\begin{array}{l}27.229 \\
42.901\end{array}$ & $\begin{array}{c}{[\mathrm{M}-\mathrm{H}]^{-}} \\
* *[\mathrm{M}-\mathrm{H}]^{-}\end{array}$ & $\begin{array}{l}\text { avones } \\
578.1636 \\
594.1585\end{array}$ & $\begin{array}{l}577.1563 \\
593.1512\end{array}$ & $\begin{array}{l}577.1538 \\
593.1485\end{array}$ & $\begin{array}{l}-4.3 \\
-4.6\end{array}$ & $\begin{array}{l}413,269 \\
503,473\end{array}$ & $\begin{array}{c}\mathrm{JM} \\
* \mathrm{JM}, \mathrm{WN}\end{array}$ \\
\hline 48 & $\mathrm{C}_{21} \mathrm{H}_{20} \mathrm{O}_{11}$ & 6-Hydroxyluteolin 7-O-rhamnoside & 46.341 & ${ }^{* *}[\mathrm{M}-\mathrm{H}]^{-}$ & 448.1006 & 447.0933 & 447.0915 & -4.0 & 301 & $\begin{array}{l}{ }^{*} \mathrm{PT}, \mathrm{JM}, \mathrm{WN}, \\
\mathrm{BB}\end{array}$ \\
\hline 49 & $\mathrm{C}_{15} \mathrm{H}_{10} \mathrm{O}_{4}$ & 7,4'-Dihydroxyflavone & 82.529 & {$[\mathrm{M}+\mathrm{H}]^{+}$} & $\begin{array}{l}254.0579 \\
\text { vonols }\end{array}$ & 255.0652 & 255.0646 & -2.4 & $227,199,171$ & * RI, BB \\
\hline 50 & $\mathrm{C}_{21} \mathrm{H}_{20} \mathrm{O}_{3}$ & Myricetin 3-O-galactoside & 19.288 & {$[\mathrm{M}-\mathrm{H}]^{-}$} & 480.0904 & 479.0831 & 479.081 & -4.4 & 317 & $\mathrm{PT}$ \\
\hline 51 & $\mathrm{C}_{27} \mathrm{H}_{30} \mathrm{O}_{17}$ & $\begin{array}{l}\text { Myricetin 3-O-rutinoside } \\
\text { Spinacetin }\end{array}$ & 31.52 & {$[\mathrm{M}-\mathrm{H}]^{-}$} & 626.1483 & 625.141 & 625.1386 & -3.8 & 301 & $\mathrm{JM}$ \\
\hline 52 & $\mathrm{C}_{43} \mathrm{H}_{48} \mathrm{O}_{24}$ & $\begin{array}{c}\text { 3-O-(2"-p-coumaroylglucosyl) }(1->6)- \\
\text { [apiosyl (1->2)]-glucoside } \\
\text { Kaempferol }\end{array}$ & 33.242 & {$[\mathrm{M}-\mathrm{H}]^{-}$} & 948.2536 & 947.2463 & 947.2456 & -0.7 & $741,609,301$ & $\mathrm{JM}$ \\
\hline 53 & $\mathrm{C}_{33} \mathrm{H}_{40} \mathrm{O}_{19}$ & $\begin{array}{c}\text { 3-O-(2"-rhamnosyl-galactoside) } \\
\text { 7-O-rhamnoside }\end{array}$ & 35.077 & {$[\mathrm{M}-\mathrm{H}]^{-}$} & 740.2164 & 739.2091 & 739.2091 & 0.0 & $593,447,285$ & RI \\
\hline 54 & $\mathrm{C}_{27} \mathrm{H}_{30} \mathrm{O}_{16}$ & Kaempferol 3,7-O-diglucoside & 37.384 & {$[\mathrm{M}-\mathrm{H}]^{-}$} & 610.1534 & 609.1461 & 609.1453 & -1.3 & 447,285 & * JM, RI \\
\hline 55 & $\mathrm{C}_{33} \mathrm{H}_{40} \mathrm{O}_{20}$ & $\begin{array}{c}\text { Kaempferol } \\
\text { 3-O-glucosyl-rhamnosyl-galactoside }\end{array}$ & 40.184 & $* *[\mathrm{M}-\mathrm{H}]^{-}$ & 756.2113 & 755.204 & 755.2047 & 0.9 & 285 & * JM, WN, RI \\
\hline 56 & $\mathrm{C}_{21} \mathrm{H}_{20} \mathrm{O}_{12}$ & Myricetin 3-O-rhamnoside & 40.234 & {$[\mathrm{M}-\mathrm{H}]^{-}$} & $\begin{array}{l}464.0955 \\
\text { avonoids }\end{array}$ & 463.0882 & 463.0882 & 0.0 & 317 & * JM, PT \\
\hline 57 & $\mathrm{C}_{15} \mathrm{H}_{12} \mathrm{O}_{4}$ & 2-Dehydro-O-desmethylangolensin & 77.899 & {$[\mathrm{M}-\mathrm{H}]^{-}$} & 256.0736 & 255.0663 & 255.0678 & 5.9 & 135,119 & $\mathrm{BB}$ \\
\hline 58 & $\mathrm{C}_{15} \mathrm{H}_{12} \mathrm{O}_{5}$ & $3^{\prime}, 4^{\prime}, 7$-Trihydroxyisoflavanone & 78.287 & {$[\mathrm{M}-\mathrm{H}]^{-}$} & 272.0685 & 271.0612 & 271.0612 & 0.0 & $\begin{array}{c}177,151,119 \\
107\end{array}$ & * JM, BB \\
\hline 59 & $\mathrm{C}_{15} \mathrm{H}_{10} \mathrm{O}_{5}$ & 3'-Hydroxydaidzein & 81.816 & ${ }^{[\mathrm{M}+\mathrm{H}]^{+}}$ & \multicolumn{5}{|c|}{ Stilbenes } & RI \\
\hline 60 & $\mathrm{C}_{20} \mathrm{H}_{22} \mathrm{O}_{8}$ & Resveratrol 5-O-glucoside & 38.063 & {$[\mathrm{M}-\mathrm{H}]^{-}$} & 390.1315 & 389.1242 & 389.1245 & 0.8 & 227 & $\mathrm{JM}$ \\
\hline
\end{tabular}


Table 3. Cont.

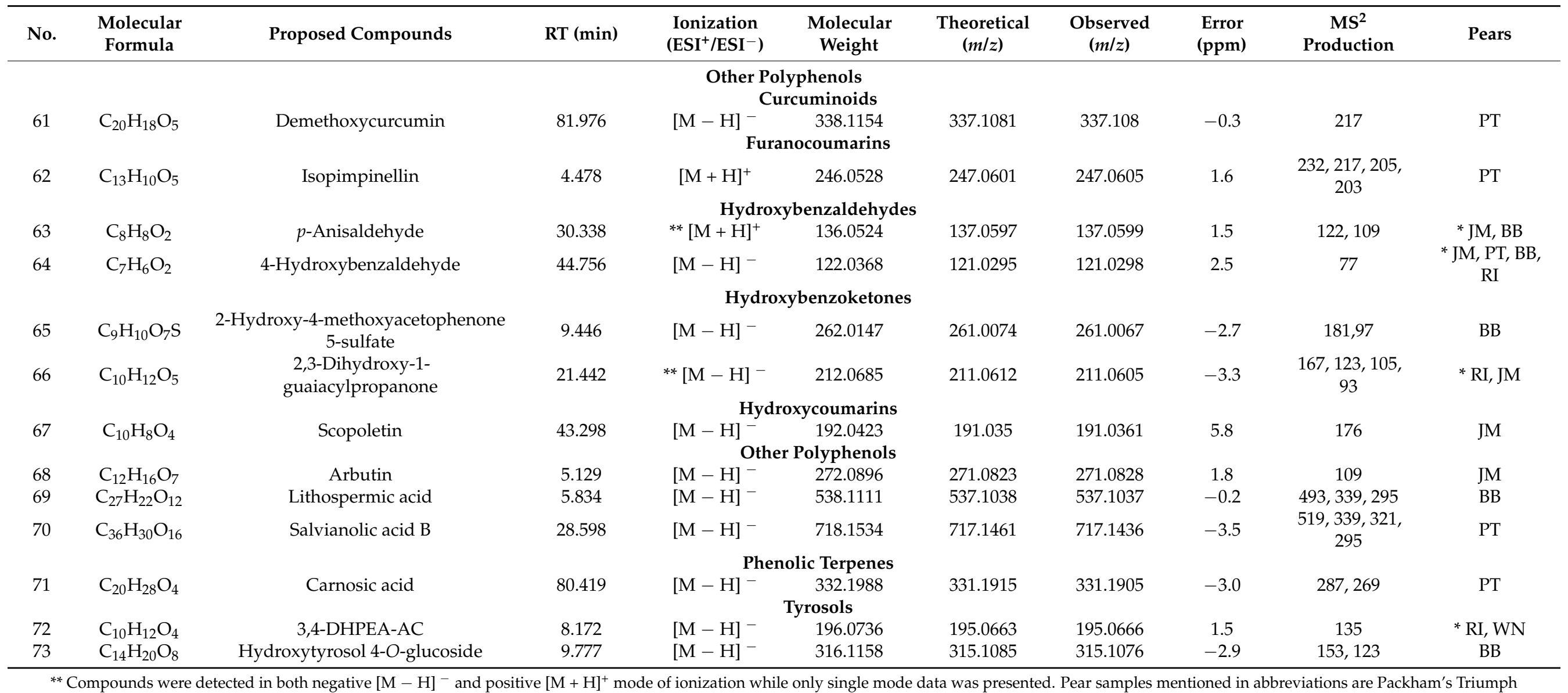

"PT", Josephine de Malines "JM", Beurre Bosc "BB", Winter Nelis "WN" and Rico "RI". 


\subsubsection{Phenolic Acids}

In this study, 4 classes of phenolic acids were detected in five pear samples (Table 3) resulting in two dominant subclasses of phenolic acids in pear samples being hydroxybenzoic acids (eight phenolic acids) and hydroxycinnamic acids (17), respectively. In addition, two hydroxyphenylacetic acids and three hydroxyphenylpropanoic acids were also identified in pear samples.

\section{Hydroxybenzoic Acids}

Hydroxybenzoic acids are widely present in different fruits and they are not only capable of inhibit $\alpha$-amylase and $\alpha$-glucosidase activity, but also reduce the enzymes responsible for breaking down complex carbohydrates, which help to control glycemia in humans [36]. According to the LC-MS results, three out of the eight different hydroxybenzoic acids were identified in only one pear sample (Compounds 1, 3, 7). Compounds 3 and 5 were both detected all pear varieties except Winter Nelis. Compound $\mathbf{3}$ was tentatively identified as gallic acid with the precursor ion $[\mathrm{M}-\mathrm{H}]^{-}$at $\mathrm{m} / z 169.0145$ and further confirmed by the $\mathrm{MS}^{2}$ experiment which shows a loss of $\mathrm{CO}_{2}(44 \mathrm{Da})$ at $m / z 125$ [37]. Furthermore, two gallic acid derivatives, which are gallic acid 3-O-gallate (compound 7) and gallic acid 4-O-gallate (compound 2) were characterized based on the precursor ion at $\mathrm{m} / \mathrm{z} 321.0239$ and $m / z 331.0675$, respectively. According to the result of the $\mathrm{MS}^{2}$ experiment, gallic acid 3-O-gallate shows a loss of galloyl moiety (152 Da) from the precursor ion at $\mathrm{m} / \mathrm{z} 169$, while gallic acid 4-O-gallate displays a loss of the glucoside moiety $(162 \mathrm{Da})$ and consecutive loss of $\mathrm{CO}_{2}(44 \mathrm{Da})$ from the precursor ion at $m / z 169$ and 125 [38,39].

In a previous study, the appearance of gallic acid in the peel and pulp of different pear varieties have been reported by Yim and Nam [4] and Li et al. [21]. Additionally, some hydroxybenzoic acids were characterized by several studies on different fruits or vegetables. For example, Rajauria et al. [38] identified the gallic acid 4-O-glucoside in Himanthalia elongata Irish seaweed by LC-DAD-ESI-MS/MS and using $60 \%$ methanol as the extracting agent. Catarino et al. [40] identified the protocatechuic-acid 4-O-glucoside in the stems of Eriocephalus africanus by LC-DAD-ESI/MS method. 2-Hydroxybenzoic acid, which is also known as salicylic acid, was identified not only in pears, but also in other fruits, including kiwifruit and grapes [41]. In the previous study, vanillic acid 4-sulfate and 2, 3-dihydroxybenzoic acid were identified by Zhong et al. [17] and Pj et al. [42] in seaweed and Flacourtia inermis fruit, respectively.

\section{Hydroxycinnamic Acids}

Only 6 out of 17 different hydroxycinnamic acids (Compounds 9, 10, 12, 15, 19, 20) were detected in more than one pear sample. Among them, compounds 10, 12, 19, 20 were identified in both positive and negative modes. Compound 22 was tentatively identified as ferulic acid according to the precursor ion $[\mathrm{M}-\mathrm{H}]^{-}$at $m / z$ 193.0499. In the $\mathrm{MS}^{2}$ experiment of compound 22, the product ion at $\mathrm{m} / \mathrm{z} 178, \mathrm{~m} / \mathrm{z} 149$ and $\mathrm{m} / \mathrm{z} 134$ were due to the loss of $\mathrm{CH}_{3}, \mathrm{CO}_{2}$ and $\mathrm{CH}_{3}$ with $\mathrm{CO}_{2}$ from the precursor, respectively [43]. Caffeic acid (Compound 12) was observed in with $[\mathrm{M}-\mathrm{H}]^{-} \mathrm{m} / \mathrm{z}$ at 179.0346 in both the negative and positive ionization mode. The identification of caffeic acid was achieved by the MS 2 experiment which displayed the product ions at $\mathrm{m} / \mathrm{z} 143$ and $\mathrm{m} / \mathrm{z} 133$ result from the loss of 2 water (36 Da) and $\mathrm{HCOOH}(46 \mathrm{Da})$, respectively [44]. Compound 10, which was present in all pear varieties except Josephine de Malines, was tentatively detected as cinnamic acid based on the precursor ion $[\mathrm{M}-\mathrm{H}]^{-} \mathrm{m} / z$ at 147.0461 in both the negative and positive ionization modes and further confirmed by the $\mathrm{MS}^{2}$ experiment which shows a loss of $\mathrm{CO}_{2}$ (44 Da) at $m / z 103$ [45].

Previously, the appearance of cinnamic acid in 10 different pear varieties had been reported by Sun et al. [46]. Furthermore, the presence of caffeic and $m$-coumaric acid in the flesh and peel of pear varieties were also determined by Öztürk et al. [47]. Simirgiotis et al. [48] identified caffeoyl glucose in the peel of the small Easter Pear. In an earlier study, ferulic acid was been identified in five different pear varieties [49,50]. Regarding other 
plants, Suleria et al. [16] characterized the feruloyl tartaric acid in pear peels and other fruit peels. In addition, Lin and Harnly [51] confirmed the appearance of the 3-caffeoylquinic acids in the pear skin. According to Ludwig et al. [52], the ferulic acid 4-O-glucuronide has been detected in the red raspberry by UHPLC-MS analysis. Piovesana and Noreña [53] isolated 3-p-coumaroylquinic acid from Hibiscus sabdariffa L. by HPLC-QTOF-MS method. In addition, coffee and stone fruit was also reported as a good source of 3-feruloylquinic acid by the previous study [54]. Regarding the rosmarinic acid, several studies have reported the presence of this compound. Hossain et al. [55] identified rosmarinic acid in Lamiaceae herbs with precursor ion $[\mathrm{M}-\mathrm{H}]^{-}$at $\mathrm{m} / \mathrm{z} 359.0763$ and the result of MS/MS is at $m / z$ 197, 179, 161 and 135 by the LC-ESI-MS/MS method. Chaowuttikul et al. [56] also characterized the rosmarinic acid in some Thai medicinal plants by the RP-HPLC-DAD method and found that the concentration is highest in Melissa officinalis leaves. In addition, some compounds, such as caffeic acid 3'-O-glucuronide and $p$-coumaroyl tartaric acid were first reported here in pears to our best knowledge.

Hydroxyphenylacetic Acids and Hydroxyphenylpropanoic Acids

Only 2 hydroxyphenylacetic acids and 3 hydroxyphenylpropanoic acids were characterized in pear samples. Compound $\mathbf{2 9}$ and compound $\mathbf{3 0}$ were both detected in the negative ionization mode with the precursor ion $[\mathrm{M}-\mathrm{H}]{ }^{-}$at $\mathrm{m} / \mathrm{z} 357.0828$ and $\mathrm{m} / \mathrm{z}$ 371.0975 and characterized as dihydrocaffeic acid 3-O-glucuronide and dihydroferulic acid 4-O-glucuronide. According to the $\mathrm{MS}^{2}$ spectra, dihydrocaffeic acid 3-O-glucuronide and dihydroferulic acid 4-O-glucuronide showed the fragments at $\mathrm{m} / \mathrm{z} 181$ and $\mathrm{m} / \mathrm{z} 195$, respectively and the characteristic loss of glucuronide (176 Da) moiety was observed in both compounds [57]. In a previous study, Cuadrado-Silva et al. [58] quantified only trace amounts of 3,4-dihydroxyphenylacetic acid in P. friedrichsthalianum fruit by the UHPLCESI/QqQ method. Trautvetter et al. [59] also identified this compound in five varieties of honey at $m / z 167.0344$ by the UPLC-MS method. However, to our best knowledge the present study is the first to report the presence of 3-hydroxy-3-(3-hydroxyphenyl) propionic acid in pears.

\subsubsection{Flavonoids}

Flavonoids are the second largest group of phenolic compounds in the five pear varieties. The subclass of flavonoids which were detected in pears include anthocyanins, dihydrochalcones, dihydroflavonols, flavanols, flavanones, flavones, flavonol and isoflavonoids. The flavanols and flavonols are the dominant subclasses among them with 7 of each group of compounds being detected.

\section{Anthocyanins, Dihydrochalcones and Dihydroflavonols}

Only 2 anthocyanins, 2 dihydrochalcones and 2 dihydroflavonols were detected in five pear varieties and both compounds $\mathbf{3 1}$ and $\mathbf{3 2}$ were detected in the positive ionization mode (Table 3). Compound 33 was identified as 3-hydroxyphloretin 2'-O-glucoside with the precursor ion $[\mathrm{M}-\mathrm{H}]^{-}$at $m / z 451.1236$ and further confirmed by the $\mathrm{MS}^{2}$ experiment which shows a loss of glucoside (162 Da) at $\mathrm{m} / \mathrm{z} 289$ and phloretin aglycon at $\mathrm{m} / \mathrm{z} 273$ [60]. In addition, compound 35 was characterized as dihydroquercetin with the precursor ion at $\mathrm{m} / z 303.0501$ in the negative $\mathrm{ESI}^{-}$mode. Dihydroquercetin was also identified according to the MS ${ }^{2}$ fragmentation which exhibited the peaks at $m / z 285, m / z 275$ and $m / z 151$ by the loss of $\mathrm{H}_{2} \mathrm{O}, \mathrm{CO}$ and 152 Da loss by RDA cleavage [61].

According to Raja et al. [62], dihydroquercetin is one of the highly specific polyphenols. They have identified this compound in two pear varieties, which are conference and Alejandrina. Previously, CHUNG [63] have identified petunidin 3-O-(6"-acetyl-glucoside) in Highbush blueberry fruit with the MS value $m / z$ at 521 and MS $^{2}$ value $m / z$ at 317 , this result is same to our research. 3-Hydroxyphloretin 2'-O-glucoside in the peel of apples was also quantified in the previous study by HPLC analysis $[64,65]$. In addition, another 
dihydrochalcone, 3-hydroxyphloretin 2'-O-xylosyl-glucoside, was also identified in apple pomace by Alvarez Arraibi [66].

\section{Flavanols}

Only two (compounds 37 and 41) out of seven flavanols were detected in more than a single pear variety. Compound $\mathbf{4 1}$ was tentatively characterized as (+)-catechin in the negative ESI' mode at $m / z 289.0712$ and further confirmed by the $\mathrm{MS}^{2}$ experiment which displayed a characteristic loss of $\mathrm{CO}_{2}(44 \mathrm{Da})$, flavonoid a ring $(84 \mathrm{Da})$ and flavonoid a ring (110 Da) at $m / z 245, \mathrm{~m} / z 205$ and $\mathrm{m} / \mathrm{z} 179$, respectively [37]. While compound 39 only presenting in Josephine de Malines in the negative ESI ${ }^{-}$mode was proposed as procyanidin dimer B1 based on the $[\mathrm{M}-\mathrm{H}]^{-} \mathrm{m} / \mathrm{z}$ at 577.1318. In the $\mathrm{MS}^{2}$ spectra, procyanidin dimer B1 showed the fragments at $\mathrm{m} / \mathrm{z} 451$ due to a loss of phloroglucinol (126 Da) [67].

Previously, Brahem et al. [7] detected the phenolic compounds in 19 pear varieties and characterized (+)-catechin in the flesh of four pear varieties and the peel of 15 pear varieties. In addition, the appearance of procyanidin dimer B1 and procyanidin trimer $\mathrm{C} 1$ in pear varieties were identified by de Pascual-Teresa et al. [68]. In the previous study, Yuzuak et al. [69] have confirmed the presence of (+)-gallocatechin in berries of Two Muscadine grape hybrids by applying HPLC-QTOF-MS/MS method. But Arts et al. [70] indicate that there was no (+)-gallocatechin in the peel and pulp of pears. The difference may result from the different pear varieties and the variance of the extraction method. In addition, (+)-catechin 3-O-gallate and 3'-O-methylcatechin were the first time identified in European pears to our best knowledge.

\section{Flavonols}

Four out of seven of flavonols were detected in only one pear varieties, which include compounds 50, 51, 52, 53 (Table 3). Only compound $\mathbf{5 5}$ was detected in both negative and positive ionization modes. Two myricetin derivatives, which are myricetin 3-O-galactoside (compound 50) and myricetin 3-O-rhamnoside (compound 56), were characterized with the precursor ion $[\mathrm{M}-\mathrm{H}]^{-}$at $m / z 479.081$ and $m / z 463.0882$ in the negative ESI' mode. In the $\mathrm{MS}^{2}$ experiment, both compound 50 and compound 56 exhibited the same product ion at $m / z 317$ after the loss of glucoside (162 Da) and rhamnoside (146 Da) [71,72]. Compound 54 was identified as kaempferol 3,7-O-diglucoside with the precursor ion $[\mathrm{M}-\mathrm{H}]^{-}$at $\mathrm{m} / \mathrm{z}$ 609.1453 in the negative ionization mode and further confirmed by the $\mathrm{MS}^{2}$ experiment which displayed a characteristic loss of glucoside (162 Da) and two glucoside (324 Da) [73].

Previously, Dairpoosh [65] have characterized myricetin 3-O-rhamnoside in pear peel. In addition, myricetin 3-O-galactoside were characterized from grape wine by LC-MS method [74]. Barbosa et al. [75] reported that myricetin 3-O-rutinoside in Chrysobalanus icaco $\mathrm{L}$. was detected in the negative mode with the quasi-molecular ion $[\mathrm{M}-\mathrm{H}]{ }^{-}$at $\mathrm{m} / \mathrm{z}$ 625 and the fragment ion at $\mathrm{m} / \mathrm{z} 317$ corresponding to the loss of rhamnose unit. They showed slightly different results from our work, which might be due to the difference in mass spectrophotometric methods and techniques applied.

Flavanones, Flavones and Isoflavonoids

In total, 2 flavanones, 4 flavones and 3 isoflavonoids were detected in pear samples with five out of nine being found in only one pear variety (Table 3). Compound 58 was characterized as $3^{\prime}, 4^{\prime}, 7$-trihydroxyisoflavanone which have the precursor ion $[\mathrm{M}-\mathrm{H}]^{-}$at $\mathrm{m} / \mathrm{z} 271.0612$ in the positive ionization mode. The identity of $3^{\prime}, 4^{\prime}, 7$-trihydroxyisoflavanone was proven by its MS/MS fragments at $\mathrm{m} / \mathrm{z} 177, \mathrm{~m} / \mathrm{z} 151$ and $\mathrm{m} / \mathrm{z} 119$, corresponding to the loss of $\mathrm{C}_{6} \mathrm{H}_{6} \mathrm{O}(94 \mathrm{Da}), \mathrm{C}_{8} \mathrm{H}_{8} \mathrm{O}(120 \mathrm{Da})$ and $\mathrm{C}_{7} \mathrm{H}_{4} \mathrm{O}_{4}(152 \mathrm{Da})$, respectively [76]. Compound 46 was detected in the negative $\mathrm{ESI}^{-}$mode and tentatively characterized as rhoifolin based on the precursor ion $[\mathrm{M}-\mathrm{H}]^{-}$at $m / z$ 577.1538. In the $\mathrm{MS}^{2}$ experiment, rhoifolin was identified based on the product ion at $\mathrm{m} / \mathrm{z} 413$ and $\mathrm{m} / \mathrm{z} 269$, produced by loss of rhamnose moiety and $\mathrm{H}_{2} \mathrm{O}(164 \mathrm{Da})$ and rhamnose moiety and glucose moiety (308 Da), respectively [76]. 
There have been very few studies focusing on the isoflavonoids in pears, although the isoflavonoid content of other fruits have been reported. Peng et al. [10] characterized $3^{\prime}$-hydroxydaidzein with $[\mathrm{M}+\mathrm{H}]^{+}$at $m / z 271$ in mango peel while 2-dehydro-Odesmethylangolensin has been identified in palm fruits and reported by Ma et al. [77]. Although no research has confirmed the presence of rhoifolin in pears, the presence of these compound in Pummelo juice and Mandarin juice has been reported by Nogata et al. [78]. Additionally, 6-hydroxyluteolin 7-O-rhamnoside can be found in Mexican oregano [79].

\subsubsection{Other Phenolic Compounds}

Thirteen other polyphenols were also detected in the pear samples, which include 1 curcuminoids, 1 furanocoumarin, 2 hydroxybenzaldehydes, 2 hydroxybenzoketones, 1 hydroxycoumarins, 1 phenolic terpene, 2 tyrosols and 3 other phenolic compounds (Table 3). Only two of these compounds (Compounds 63 and 66), were observed in both negative and positive ionization modes. Compound 64 and was found in in all pear varieties except Winter Nelis and was identified as 4-hydroxybenzaldehyde having the precursor ion $[\mathrm{M}-\mathrm{H}]^{-}$at $m / z 121.0298$ in the negative ionization mode and further confirmed by the MS ${ }^{2}$ experiment which displayed a characteristic loss of $\mathrm{CO}_{2}$ (44Da) [80]. Compound 68 was tentatively characterized in the negative ionization mode as arbutin based on the precursor ion $[\mathrm{M}-\mathrm{H}]^{-}$at $m / z 271.0828$ and further identified by MS/MS spectra which showed a loss of glucoside (162 Da) [81]. In addition, carnosic acid (compound 71) was observed in Packham's Triumph with the precursor ion $[\mathrm{M}-\mathrm{H}]{ }^{-}$at $\mathrm{m} / \mathrm{z}$ 331.1905. In the $\mathrm{MS}^{2}$ spectra of carnosic acid, the product ion at $\mathrm{m} / \mathrm{z} 287$ and $\mathrm{m} / \mathrm{z} 269$ were due to the loss $\mathrm{CO}_{2}$ and further loss of $\mathrm{H}_{2} \mathrm{O}$ from the parent ion [82].

Arbutin is an important phenolic compound with antibiotic properties and has been confirmed as the dominant phenolic compounds in 8 varieties of pears by Öztürk et al. [47] and $\mathrm{Li}$ et al. [83]. Some of the other compounds were reported in other plants but not pears. Pistelli et al. [84] have identified the presence of demethoxycurcumin in Curcuma longa by LC-DAD-ESI-MS method. While the presence of isopimpinellin have also been confirmed by Dehghan et al. [85] in Heracleum persicum. In addition, Welke et al. [86] used comprehensive two-dimensional gas chromatography to identify $p$-anisaldehyde in the Chardonnay wine. In addition, both lithospermic acid salvianolic acid B were identified in Chinese Wild Salvia miltiorrhiza based on UPLC-QqQ-MS method by Zhang et al. [87]. In addition, although carnosic acid was not identified in pears to our best knowledge, but it has been reported widely distributed in the plant species of the Lamiaceae family [88].

\subsection{HPLC Analysis}

In the present work, the quantification of phenolic compounds was based on comparing retention time with HPLC grade reference standards. In total, 10 phenolic compounds were quantified through HPLC-PDA, including five targeted phenolic acids (gallic acid, protocatechuic acid, $p$-hydroxybenzoic acid, chlorogenic acid and caffeic acid) and five flavonoids (catechin, epicatechin, epicatechin gallate, quercetin and kaempferol) (Table 4).

Beurre Bosc has the highest phenolic acid contents while Winter Nelis and Rico have lower phenolic acids contents (Table 4) which is consistent with the other estimations of TPC in the present study. Among the five targeted phenolic acids, protocatechuic acid was only detected in Beurre Bosc, Josephine de Malines and Packham's Triumph. In addition, a small amount of $p$-hydroxybenzoic acid was detected in five pear varieties, which ranged from $0.95 \pm 0.05 \mathrm{mg} / \mathrm{g}$ to $3.14 \pm 0.15 \mathrm{mg} / \mathrm{g}$. They were abundant in Packham's Triumph and less abundant in Josephine de Malines and Rico, respectively. Chlorogenic acid is the dominant phenolic acids among the five selected phenolic acids. It is abundant in all five pear varieties except Rico. Previously, both Öztürk et al. [47] and Liaudanskas et al. [89] have reported that chlorogenic acid is the dominant phenolic compounds in several Lithuania and Sinop grown pear varieties, including Conference, Concordia, Grabova and Patten. Further, protocatechuic acid was also previously quantified by Truong et al. [90] through HPLC analysis in the Asian grown pear varieties (Pyrus spp.). In addition, Tanriöven 
and Ekşi [91] have quantitated chlorogenic acid and caffeic acid in pear juice using HPLC method from several pear varieties, for instance, Williams, Santa Maria and Starkrimson. In the previous study, both Li et al. [21] and Li et al. [92] have quantitated the gallic acid in different pear varieties growing in China, which includes P. bretschneideri, P. pyrifolia, P. pyrifolia Nakai and Pyrus sp. nr. Communis.

Table 4. Quantification of phenolic compounds in pears by using HPLC-PDA.

\begin{tabular}{|c|c|c|c|c|c|c|c|c|}
\hline No. & Compound Name & RT (min) & $\begin{array}{l}\text { Beurre Bosc } \\
(\mathrm{mg} / \mathrm{g})\end{array}$ & $\begin{array}{c}\text { Josephine de } \\
\text { Malines } \\
\text { (mg/g) }\end{array}$ & $\begin{array}{l}\text { Packham's } \\
\text { Triumph } \\
\text { (mg/g) }\end{array}$ & $\begin{array}{l}\text { Winter Nelis } \\
(\mathrm{mg} / \mathrm{g})\end{array}$ & Rico (mg/g) & $\begin{array}{l}\text { Polyphenol } \\
\text { Classes }\end{array}$ \\
\hline 1 & Gallic acid & 6.836 & $5.68 \pm 0.34^{\mathrm{a}}$ & $3.25 \pm 0.16^{\mathrm{b}}$ & $0.25 \pm 0.02^{\mathrm{d}}$ & $1.28 \pm 0.07^{\mathrm{c}}$ & $2.43 \pm 0.21^{b}$ & Phenolic acid \\
\hline 2 & Protocatechuic acid & 12.569 & $3.54 \pm 0.31^{\mathrm{a}}$ & $1.27 \pm 0.11^{c}$ & $2.41 \pm 0.12^{b}$ & - & - & Phenolic acid \\
\hline 3 & $p$-Hydroxybenzoic acid & 20.24 & $2.15 \pm 0.17^{b}$ & $1.64 \pm 0.11^{c}$ & $3.14 \pm 0.15^{\mathrm{a}}$ & $2.14 \pm 0.10^{\mathrm{b}}$ & $0.95 \pm 0.05^{\mathrm{d}}$ & Phenolic acid \\
\hline 4 & Chlorogenic acid & 20.579 & $17.58 \pm 0.88^{a}$ & $9.78 \pm 0.78^{\mathrm{d}}$ & $12.35 \pm 0.99^{c}$ & $14.51 \pm 0.87^{\mathrm{b}}$ & $1.53 \pm 0.13^{\mathrm{e}}$ & Phenolic acid \\
\hline 5 & Caffeic acid & 25.001 & $3.58 \pm 0.21^{b}$ & $1.85 \pm 0.11^{\mathrm{c}}$ & $2.48 \pm 0.14^{\mathrm{c}}$ & $0.98 \pm 0.09 \mathrm{~d}$ & $4.57 \pm 0.36^{\mathrm{a}}$ & Phenolic acid \\
\hline 6 & Catechin & 19.704 & $14.89 \pm 0.89^{b}$ & $17.45 \pm 1.39^{\mathrm{a}}$ & $4.59 \pm 0.41^{\mathrm{e}}$ & $9.45 \pm 0.75^{d}$ & $11.25 \pm 1.01^{\mathrm{c}}$ & Flavonoid \\
\hline 7 & Epicatechin & 24.961 & $6.98 \pm 0.49^{a}$ & $3.64 \pm 0.15^{b}$ & $2.37 \pm 0.19^{c}$ & $1.58 \pm 0.14^{\mathrm{d}}$ & $2.31 \pm 0.20^{c}$ & Flavonoid \\
\hline 8 & Epicatechin gallate & 38.015 & $2.31 \pm 0.11^{\mathrm{a}}$ & $1.89 \pm 0.13^{\mathrm{a}}$ & - & - & $1.25 \pm 0.08^{b}$ & Flavonoid \\
\hline 9 & Quercetin & 70.098 & $6.38 \pm 0.44^{b}$ & $14.57 \pm 1.01^{\mathrm{a}}$ & $3.28 \pm 0.16^{c}$ & $5.49 \pm 0.44^{b}$ & $4.58 \pm 0.23^{b}$ & Flavonoid \\
\hline 10 & Kaempferol & 80.347 & $3.37 \pm 0.17^{c}$ & $4.58 \pm 0.41^{\mathrm{b}}$ & $8.59 \pm 0.60^{a}$ & $3.27 \pm 0.16^{c}$ & $1.28 \pm 0.10^{\mathrm{d}}$ & Flavonoid \\
\hline
\end{tabular}

All data are the mean \pm SD of three replicates. Means followed by different letters $\left({ }^{a, b, c, d, e}\right)$ within the same column are significantly different $(p<0.05)$ of each other. Data of Packham's Triumph, Josephine de Malines, Beurre Bosc, Winter Nelis and Rico are reported on a dry weight basis.

Regarding flavonoids, catechin is the major flavonoids in the five pear varieties except for Packham's Triumph. It is also the dominant flavonoids among the five selected flavonoids, this is consistent with the conclusion from Öztürk et al. [89]. In a small amount, epicatechin gallate was only detected in three pear varieties, which are Beurre Bosc, Josephine de Malines and Rico. Epicatechin is high in Beurre Bosc but less abundant in Winter Nelis. In addition, quercetin is abundant in Josephine de Malines and low in Packham's Triumph and Rico. In the previous study, Brahem et al. [7] also quantified the epicatechin in the flesh and peel of 16 European grown pear varieties (such as Rochas, William rouge and William vert) and found that the concentration is higher in the peel than flesh. However, Arts et al. [70] quantified that there is no epicatechin gallate detected in 2 Netherlands grown pear varieties, including Conference and Doyenne du Comice. This may be due to the difference in pear varieties, growing regions and extraction solvent.

\section{Conclusions}

Based on these data, Beurre Bosc has the highest TPC, TTC and DPPH concentrations while Josephine de Malines was high in TFC, ABTS, FRAP and TAC values. Winter Nelis was consistently low across the antioxidant assays except for TAC. The present work successfully employed LC-ESI-QTOF-MS/MS analysis to sperate and identify the phenolic profile in the pulp of five Australian grown pear varieties. A total of 73 phenolic compounds were detected in the five Australian grown pear varieties studied. The present work also used HPLC to quantify the phenolic compounds in pears and a total of five phenolic acids and five flavonoids were quantified. Chlorogenic acid and catechin are the dominant phenolic compounds in pears. This project provides comprehensive qualitative and quantitative information about the phenolic compounds present in Australian grown pears. These data may be useful for developing strategies and products in the nutraceutical, pharmaceutical and food industries.

Supplementary Materials: The following are available online at https: / /www.mdpi.com/2076-3 921/10/2/151/s1, Figure S1: LC-ESI-QTOF-MS/MS basic peak chromatograph (BPC) for characterization of phenolic compounds of Australian grown pear varieties. Figure S2. Extracted ion chromatogram of pear sample and their mass spectrum. 
Author Contributions: Conceptualization, methodology, formal analysis, validation and investigation, Z.W. and H.A.R.S.; resources, H.A.R.S., C.J.B. and F.R.D.; writing-original draft preparation, Z.W. and H.A.R.S.; writing-review and editing, Z.W., C.J.B., H.A.R.S. and F.R.D.; supervision, H.A.R.S. and F.R.D.; ideas sharing, H.A.R.S.; C.J.B. and F.R.D.; funding acquisition, H.A.R.S., F.R.D. and C.J.B. All authors have read and agreed to the published version of the manuscript.

Funding: This research was funded by the University of Melbourne under the "McKenzie Fellowship Scheme" (Grant No. UoM-18/21), the "Richard WS Nicholas Agricultural Science Scholarship" and the "Faculty Research Initiative Funds" funded by the Faculty of Veterinary and Agricultural Sciences, The University of Melbourne, Australia and "The Alfred Deakin Research Fellowship" funded by Deakin University, Australia.

Institutional Review Board Statement: Not applicable.

Informed Consent Statement: Not applicable.

Data Availability Statement: Not applicable.

Acknowledgments: We would like to thank Nicholas Williamson, Shuai Nie and Michael Leeming from the Mass Spectrometry and Proteomics Facility, Bio21 Molecular Science and Biotechnology Institute, the University of Melbourne, VIC, Australia for providing access and support for the use of HPLC-PDA and LC-ESI-QTOF-MS/MS and data analysis.

Conflicts of Interest: The authors declare no conflict of interest.

\section{References}

1. Kolniak-Ostek, J. Chemical composition and antioxidant capacity of different anatomical parts of pear (Pyrus communis L.). Food Chem. 2016, 203, 491-497. [CrossRef]

2. Silva, G.J.; Souza, T.M.; Barbieri, R.L.; De Oliveira, A.C. Origin, Domestication, and Dispersing of Pear (Pyrus spp.). Adv. Agric. 2014, 2014, 1-8. [CrossRef]

3. Jun-feng, G.; Xiao-dong, D. Present situation and future of pear processing technology in china. Storage Process 2017, 17, 1-4.

4. Yim, S.; Nam, S. Physiochemical, nutritional and functional characterization of 10 different pear cultivars (pyrus spp.). J. Appl. Bot. Food Qual. 2016, 89, 73-81.

5. Borges, G.; Mullen, W.; Crozier, A. Comparison of the polyphenolic composition and antioxidant activity of European commercial fruit juices. Food Funct. 2010, 1, 73-83. [CrossRef]

6. Katz, I.H.; Nagar, E.E.; Okun, Z.; Shpigelman, A. The Link between Polyphenol Structure, Antioxidant Capacity and Shelf-Life Stability in the Presence of Fructose and Ascorbic Acid. Molecules 2020, 25, 225. [CrossRef]

7. Brahem, M.; Renard, C.M.; Eder, S.; Loonis, M.; Ouni, R.; Mars, M.; Le Bourvellec, C. Characterization and quantification of fruit phenolic compounds of European and Tunisian pear cultivars. Food Res. Int. 2017, 95, 125-133. [CrossRef]

8. Amorati, R.; Valgimigli, L. Advantages and limitations of common testing methods for antioxidants. Free Radic. Res. 2015, 49, 633-649. [CrossRef]

9. Jie, Z.; Hongbao, W.; Jiajun, K.; Xiaofei, S.; Shutian, T. Purification and antioxidant activity of polyphenols from young pear fruits. Food Sci. China 2017, 38, 14-20.

10. Peng, D.; Zahid, H.F.; Ajlouni, S.; Dunshea, F.R.; Suleria, H.A.R. LC-ESI-QTOF/MS Profiling of Australian Mango Peel By-Product Polyphenols and Their Potential Antioxidant Activities. Process 2019, 7, 764. [CrossRef]

11. Tang, J.; Dunshea, F.R.; Suleria, H.A.R. LC-ESI-QTOF/MS Characterization of Phenolic Compounds from Medicinal Plants (Hops and Juniper Berries) and Their Antioxidant Activity. Foods 2019, 9, 7. [CrossRef]

12. Samsonowicz, M.; Regulska, E.; Karpowicz, D.; Leśniewska, B. Antioxidant properties of coffee substitutes rich in polyphenols and minerals. Food Chem. 2019, 278, 101-109. [CrossRef]

13. Stavrou, I.J.; Christou, A.; Kapnissi-Christodoulou, C.P. Polyphenols in carobs: A review on their composition, antioxidant capacity and cytotoxic effects, and health impact. Food Chem. 2018, 269, 355-374. [CrossRef]

14. Sogi, D.S.; Siddiq, M.; Greiby, I.; Dolan, K.D. Total phenolics, antioxidant activity, and functional properties of 'Tommy Atkins' mango peel and kernel as affected by drying methods. Food Chem. 2013, 141, 2649-2655. [CrossRef]

15. Subbiah, V.; Zhong, B.; Nawaz, M.A.; Barrow, C.J.; Dunshea, F.R.; Suleria, H.A.R. Screening of Phenolic Compounds in Australian Grown Berries by LC-ESI-QTOF-MS/MS and Determination of Their Antioxidant Potential. Antioxidants 2021, 10, 26. [CrossRef]

16. Suleria, H.A.R.; Barrow, C.J.; Dunshea, F.R. Screening and Characterization of Phenolic Compounds and Their Antioxidant Capacity in Different Fruit Peels. Foods 2020, 9, 1206. [CrossRef]

17. Zhong, B.; Robinson, N.A.; Warner, R.; Barrow, C.J.; Dunshea, F.R.; Suleria, H.A.R. LC-ESI-QTOF-MS/MS Characterization of Seaweed Phenolics and Their Antioxidant Potential. Mar. Drugs 2020, 18, 331. [CrossRef]

18. Erbil, N.; Murathan, Z.T.; Arslan, M.; Ilcim, A.; Sayin, B. Antimicrobial, Antioxidant, and Antimutagenic Activities of Five Turkish Pear Cultivars. Erwerbs-Obstbau 2018, 60, 203-209. [CrossRef] 
19. Manzoor, M.; Anwar, F.; Bhatti, I.A.; Jamil, A. Variation of phenolics and antioxidant activity between peel and pulp parts of pear (pyrus communis L.) fruit. Pak. J. Bot. 2013, 45, 1521-1525.

20. Azzini, E.; Maiani, G.; Durazzo, A.; Foddai, M.S.; Intorre, F.; Venneria, E.; Forte, V.; Lucchetti, S.; Ambra, R.; Pastore, G.; et al. Giovanni Varieties (Pyrus communis L.): Antioxidant Properties and Phytochemical Characteristics. Oxidative Med. Cell. Longev. 2019, 2019, 6714103-8. [CrossRef]

21. Li, X.; Wang, T.; Zhou, B.; Gao, W.; Cao, J.; Huang, L. Chemical composition and antioxidant and anti-inflammatory potential of peels and flesh from 10 different pear varieties (Pyrus spp.). Food Chem. 2014, 152, 531-538. [CrossRef]

22. Rawat, P.; Saroj, N.; Rawat, P.; Kumar, P.; Singh, T.D.; Pal, M. Evaluation for total phenolic, total flavonoid and antioxidant activity of leaves and roots of pyrus pashia. Int. J. Med. Pharm. Res 2015, 1, 193-196.

23. Patricia, V.M.; Syaputri, F.N.; Tugon, T.D.A.; Mardhatillah, A. Antioxidant Properties of Pyrus communis and Pyrus pyrifolia Peel Extracts. Borneo J. Pharm. 2020, 3, 64-70. [CrossRef]

24. Ma, J.N.; Wang, S.L.; Zhang, K.; Wu, Z.G.; Hattori, M.; Chen, G.L.; Ma, C.M. Chemical components and antioxidant activity of the peels of commercial apple-shaped pear (fruit of pyrus pyrifolia cv. Pingguoli). J. Food Sci. 2012, 77, C1097-C1102.

25. Velmurugan, C.; Bhargava, A. Total phenolic, flavonoids and tannin content of various extracts from pyrus communis fruit. Int. J. Pharm. Anal. Res. 2014, 3, 384-390.

26. Nomura, K.; Takaoka, M.; Uematsu, C.; Ieguchi, T.; Katayama, H. Pear (pyrus 1.) genetic resources from northern japan: Evaluation of antioxidant capacity. In Proceedings of the XII International Pear Symposium 1094, Leuven, Belgium, 14-18 July 2014; pp. 539-548.

27. Galvis-Sánchez, A.C.; Gil-Izquierdo, A.; Gil, M.I. Comparative study of six pear cultivars in terms of their phenolic and vitamin C contents and antioxidant capacity. J. Sci. Food Agric. 2003, 83, 995-1003. [CrossRef]

28. Syrgiannidis, G.; Sotiropoulos, T.; Petridis, A.; Therios, I. 'Vergina' pear. HortScience 2011, 46, $130-131$.

29. Sotiropoulos, T.; Koutinas, N.; Giannakoula, A. 'Naoussa' pear. HortScience 2016, 51, 1438-1439.

30. Gu, C.; Howell, K.; Dunshea, F.R.; Suleria, H.A.R. LC-ESI-QTOF/MS Characterisation of Phenolic Acids and Flavonoids in Polyphenol-Rich Fruits and Vegetables and Their Potential Antioxidant Activities. Antioxidants 2019, 8, 405. [CrossRef]

31. Jamuna, K.; Ramesh, C.; Srinivasa, T.; Raghu, K. In vitro antioxidant studies in some common fruits. Int. J. Pharm. Pharm. Sci. 2011, 3, 60-63.

32. Batista, S.; Guiné, R.; Barroca, M.J.; Gonçalves, F.; Pérez, M.D.; San José, M.; Ferreira, D. Sun-dried pears: Phenolic compounds and antioxidant activity. $7^{\circ}$ Encontro Química Aliment. 2005, 2-18.

33. Jamuna, K.; Ramesh, C.; Srinivasa, T.; Raghu, K. Total antioxidant capacity in aqueous extracts of some common fruits. Int. J. Pharm. Sci. Res. 2011, 2, 448.

34. Floegel, A.; Kim, D.-O.; Chung, S.-J.; Koo, S.I.; Chun, O.K. Comparison of ABTS/DPPH assays to measure antioxidant capacity in popular antioxidant-rich US foods. J. Food Compos. Anal. 2011, 24, 1043-1048. [CrossRef]

35. Du, G.; Li, M.; Ma, F.; Liang, D. Antioxidant capacity and the relationship with polyphenol and Vitamin C in Actinidia fruits. Food Chem. 2009, 113, 557-562. [CrossRef]

36. Luna-Guevara, M.L.; Luna-Guevara, J.J.; Hernández-Carranza, P.; Ruíz-Espinosa, H.; Ochoa-Velasco, C.E. Phenolic compounds: A good choice against chronic degenerative diseases. In Studies in Natural Products Chemistry; Elsevier: Amsterdam, The Netherlands, 2018; Volume 59, pp. 79-108.

37. Escobar-Avello, D.; Lozano-Castellón, J.; Mardones, C.; Pérez, A.J.; Saéz, V.; Riquelme, S.; von Baer, D.; Vallverdú-Queralt, A. Phenolic profile of grape canes: Novel compounds identified by lc-esi-ltq-orbitrap-ms. Molecules 2019, $24,3763$.

38. Rajauria, G.; Foley, B.; Abu-Ghannam, N. Identification and characterization of phenolic antioxidant compounds from brown Irish seaweed Himanthalia elongata using LC-DAD-ESI-MS/MS. Innov. Food Sci. Emerg. Technol. 2016, 37, 261-268. [CrossRef]

39. Chen, S.; Lu, C.; Zhao, R. Identification and Quantitative Characterization of PSORI-CM01, a Chinese Medicine Formula for Psoriasis Therapy, by Liquid Chromatography Coupled with an LTQ Orbitrap Mass Spectrometer. Molecules 2015, 20, 1594-1609. [CrossRef]

40. Catarino, M.D.; Silva, A.M.; Saraiva, S.C.; Sobral, A.J.; Cardoso, S.M. Characterization of phenolic constituents and evaluation of antioxidant properties of leaves and stems of Eriocephalus africanus. Arab. J. Chem. 2018, 11, 62-69. [CrossRef]

41. Robertson, G.L.; Kermode, W.J. Salicylic acid in fresh and canned fruit and vegetables. J. Sci. Food Agric. 1981, 32, 833-836. [CrossRef]

42. Pj, B.; Shibumon, G.; Sunny, K.; Cincy, G. 2,3-dihydroxybenzoic acid: An effective antifungal agent isolated from flacourtia inermis fruit. Int. J. Pharm. Clin. Res. 2010, 2, 101-105.

43. Wang, J.; Jia, Z.; Zhang, Z.; Wang, Y.; Liu, X.; Wang, L.; Lin, R. Analysis of Chemical Constituents of Melastoma dodecandrum Lour. by UPLC-ESI-Q-Exactive Focus-MS/MS. Molecules 2017, 22, 476. [CrossRef]

44. Lin, H.; Zhu, H.; Tan, J.; Wang, H.; Wang, Z.; Li, P.; Zhao, C.; Liu, J. Comparative analysis of chemical constituents of moringa oleifera leaves from china and india by ultra-performance liquid chromatography coupled with quadrupole-time-of-flight mass spectrometry. Molecules 2019, 24, 942. [CrossRef]

45. Lai, K.-M.; Cheng, Y.-Y.; Tsai, T.-H. Integrated LC-MS/MS Analytical Systems and Physical Inspection for the Analysis of a Botanical Herbal Preparation. Molecules 2015, 20, 10641-10656. [CrossRef]

46. Sun, L.; Tao, S.; Zhang, S. Characterization and Quantification of Polyphenols and Triterpenoids in Thinned Young Fruits of Ten Pear Varieties by UPLC-Q TRAP-MS/MS. Molecules 2019, 24, 159. [CrossRef] 
47. Öztürk, A.; Demirsoy, L.; Demirsoy, H.; Asan, A.; Gül, O. Phenolic compounds and chemical characteristics of pears (pyrus communis 1.). Int. J. Food Prop. 2014, 18, 536-546.

48. Simirgiotis, M.; Quispe, C.; Bórquez, J.; Areche, C.; Sepulveda, B. Fast Detection of Phenolic Compounds in Extracts of Easter Pears (Pyrus communis) from the Atacama Desert by Ultrahigh-Performance Liquid Chromatography and Mass Spectrometry (UHPLC-Q/Orbitrap/MS/MS). Molecules 2016, 21, 92. [CrossRef]

49. Hudina, M.; Stampar, F.; Orazem, P.; Petkovsek, M.M.; Veberic, R. Phenolic compounds profile, carbohydrates and external fruit quality of the 'Concorde' pear (Pyrus communis L.) after bagging. Can. J. Plant Sci. 2012, 92, 67-75. [CrossRef]

50. Salta, J.; Martins, A.; Dos Santos, R.G.; Neng, N.; Nogueira, J.; Justino, J.; Rauter, A.P. Phenolic composition and antioxidant activity of Rocha pear and other pear cultivars-A comparative study. J. Funct. Foods 2010, 2, 153-157. [CrossRef]

51. Lin, L.-Z.; Harnly, J.M. Phenolic compounds and chromatographic profiles of pear skins (Pyrus spp.). J. Agric. Food Chem. 2008, $56,9094-9101$

52. Ludwig, I.A.; Mena, P.; Calani, L.; Borges, G.; Pereira-Caro, G.; Bresciani, L.; Del Rio, D.; Lean, M.E.; Crozier, A. New insights into the bioavailability of red raspberry anthocyanins and ellagitannins. Free Radic. Biol. Med. 2015, 89, 758-769. [CrossRef]

53. Piovesana, A.; Noreña, C.P.Z. Study of Acidified Aqueous Extraction of Phenolic Compounds from Hibiscus sabdariffa L. calyces. Open Food Sci. J. 2019, 11, 25-34. [CrossRef]

54. Zamora-Ros, R.; Knaze, V.; Rothwell, J.A.; Hémon, B.; Moskal, A.; Overvad, K.; Tjønneland, A.; Kyrø, C.; Fagherazzi, G.; Boutron-Ruault, M.-C.; et al. Dietary polyphenol intake in Europe: The European Prospective Investigation into Cancer and Nutrition (EPIC) study. Eur. J. Nutr. 2016, 55, 1359-1375. [CrossRef]

55. Hossain, M.B.; Rai, D.K.; Brunton, N.P.; Martin-Diana, A.B.; Barry-Ryan, C. Characterization of phenolic composition in lamiaceae spices by lc-esi-ms/ms. J. Agric. Food Chem. 2010, 58, 10576-10581.

56. Chaowuttikul, C.; Palanuvej, C.; Ruangrungsi, N. Quantification of chlorogenic acid, rosmarinic acid, and caffeic acid contents in selected Thai medicinal plants using RP-HPLC-DAD. Braz. J. Pharm. Sci. 2020, 56, 56. [CrossRef]

57. Sasot, G.; Martínez-Huélamo, M.; Vallverdú-Queralt, A.; Mercader-Martí, M.; Estruch, R.; Lamuela-Raventós, R.M. Identification of phenolic metabolites in human urine after the intake of a functional food made from grape extract by a high resolution LTQ-Orbitrap-MS approach. Food Res. Int. 2017, 100, 435-444. [CrossRef]

58. Cuadrado-Silva, C.T.; Pozo-Bayon, M.A.; Osorio, C. Targeted Metabolomic Analysis of Polyphenols with Antioxidant Activity in Sour Guava (Psidium friedrichsthalianum Nied.) Fruit. Molecules 2016, 22, 11. [CrossRef]

59. Trautvetter, S.; Koelling-Speer, I.; Speer, K. Confirmation of phenolic acids and flavonoids in honeys by UPLC-MS. Apidologie 2009, 40, 140-150. [CrossRef]

60. Petkovska, A.; Gjamovski, V.; Stanoeva, J.P.; Stefova, M. Characterization of the Polyphenolic Profiles of Peel, Flesh and Leaves of Malus domestica Cultivars Using UHPLC-DAD-HESI-MSn. Nat. Prod. Commun. 2017, 12, 12. [CrossRef]

61. Chen, G.; Li, X.; Saleri, F.D.; Guo, M. Analysis of Flavonoids in Rhamnus davurica and Its Antiproliferative Activities. Molecules 2016, 21, 1275. [CrossRef]

62. Raja, M.; Hernández-Revelles, J.; Hernández-Cassou, S.; Saurina, J. Determination of polyphenols in the pear pulp matrix by solvent extraction and liquid chromatography with UV-Vis detection. Anal. Methods 2014, 6, 9769-9776. [CrossRef]

63. Chung, S.W. Anthocyanin Biosynthesis Associated with Skin Coloration in Highbush Blueberry Fruit During Ripening. Ph.D. Thesis, Seoul National University, Seoul, Korea, 2019.

64. Tsao, R.; Yang, R.; Young, A.J.C.; Zhu, H. Polyphenolic Profiles in Eight Apple Cultivars Using High-Performance Liquid Chromatography (HPLC). J. Agric. Food Chem. 2003, 51, 6347-6353. [CrossRef]

65. Dairpoosh, F. Profile of Polyphenols in a European Diet. Ph.D. Thesis, Jacobs University, Bremen, Germany, 2011.

66. Alvarez Arraibi, A. Cosmeceutical Potential of Apple Pomace Phenolic Compounds: Development of a Natural-Based Dermal Hydrogel as Proof of Concept. Ph.D. Thesis, University of Salamanca, Salamanca, Spain, 2018.

67. Lv, Q.; Luo, F.; Zhao, X.; Liu, Y.; Hu, G.; Sun, C.; Li, X.; Chen, K. Identification of Proanthocyanidins from Litchi (Litchi chinensis Sonn.) Pulp by LC-ESI-Q-TOF-MS and Their Antioxidant Activity. PLoS ONE 2015, 10, e0120480. [CrossRef]

68. De Pascual-Teresa, S.; Santos-Buelga, C.; Rivas-Gonzalo, J.C. Quantitative Analysis of Flavan-3-ols in Spanish Foodstuffs and Beverages. J. Agric. Food Chem. 2000, 48, 5331-5337. [CrossRef]

69. Yuzuak, S.; Ballington, J.; Xie, D.Y. Hplc-qtof-ms/ms-based profiling of flavan-3-ols and dimeric proanthocyanidins in berries of two muscadine grape hybrids flh 13-11 and flh 17-66. Metabolites 2018, 8, 57.

70. Arts, I.C.W.; Van De Putte, B.; Hollman, P.C.H. Catechin Contents of Foods Commonly Consumed in the Netherlands. 1. Fruits, Vegetables, Staple Foods, and Processed Foods. J. Agric. Food Chem. 2000, 48, 1746-1751. [CrossRef]

71. Long, W.; Ye, Z.; Ping, W.; Zhen, X.; Zhuang, W.J.; Chong, L.; Qiong, L. Rapid separation and identification of multiple constituents in vine tea by uflc system coupled with qtof-ms/ms. J. Pharm. Sci. Innov. 2015, 4, 120-126.

72. Riethmüller, E.; Tóth, G.; Alberti, Á.; Végh, K.; Burlini, I.; Könczöl, Á.; Balogh, G.T.; Kéry, Á. First characterisation of flavonoid-and diarylheptanoid-type antioxidant phenolics in corylus maxima by hplc-dad-esi-ms. J. Pharm. Biomed. Anal. 2015, 107, $159-167$.

73. Guijarro-Díez, M.; Nozal, L.; Marina, M.L.; Crego, A.L. Metabolomic fingerprinting of saffron by LC/MS: Novel authenticity markers. Anal. Bioanal. Chem. 2015, 407, 7197-7213. [CrossRef]

74. Lantzouraki, D.Z.; Sinanoglou, V.J.; Tsiaka, T.; Proestos, C.; Zoumpoulakis, P. Total phenolic content, antioxidant capacity and phytochemical profiling of grape and pomegranate wines. RSC Adv. 2015, 5, 101683-101692. [CrossRef] 
75. Barbosa, W.L.R.; Peres, A.; Gallori, S.; Vincieri, F.F. Determination of myricetin derivatives in Chrysobalanus icaco L. (Chrysobalanaceae). Rev. Bras. Farm. 2006, 16, 333-337. [CrossRef]

76. Zeng, X.; Su, W.; Zheng, Y.; Liu, H.; Li, P.; Zhang, W.; Liang, Y.; Bai, Y.; Peng, W.; Yao, H. UFLC-Q-TOF-MS/MS-Based Screening and Identification of Flavonoids and Derived Metabolites in Human Urine after Oral Administration of Exocarpium Citri Grandis Extract. Molecules 2018, 23, 895. [CrossRef]

77. Ma, C.; Dunshea, F.R.; Suleria, H.A.R. LC-ESI-QTOF/MS Characterization of Phenolic Compounds in Palm Fruits (Jelly and Fishtail Palm) and Their Potential Antioxidant Activities. Antioxidants 2019, 8, 483. [CrossRef]

78. Nogata, Y.; Ohta, H.; Yoza, K.-I.; Berhow, M.; Hasegawa, S. High-performance liquid chromatographic determination of naturally occurring flavonoids in Citrus with a photodiode-array detector. J. Chromatogr. A 1994, 667, 59-66. [CrossRef]

79. Lin, L.-Z.; Mukhopadhyay, S.; Robbins, R.J.; Harnly, J.M. Identification and quantification of flavonoids of Mexican oregano (Lippia graveolens) by LC-DAD-ESI/MS analysis. J. Food Compos. Anal. 2007, 20, 361-369. [CrossRef]

80. Wang, Y.; Vorsa, N.; Harrington, P.D.B.; Chen, P. Nontargeted Metabolomic Study on Variation of Phenolics in Different Cranberry Cultivars Using UPLC-IM-HRMS. J. Agric. Food Chem. 2018, 66, 12206-12216. [CrossRef]

81. Vuković, N.L.; Vukić, M.D.; Đelić, G.T.; Kacaniova, M.M.; Cvijović, M. The investigation of bioactive secondary metabolites of the methanol extract of eryngium amethystinum. Kragujev. J. Sci. 2018, 40, 113-129.

82. Pacifico, S.; Piccolella, S.; Lettieri, A.; Nocera, P.; Bollino, F.; Catauro, M. A metabolic profiling approach to an Italian sage leaf extract (SoA541) defines its antioxidant and anti-acetylcholinesterase properties. J. Funct. Foods 2017, 29, 1-9. [CrossRef]

83. Li, X.; Zhang, J.-Y.; Gao, W.-Y.; Wang, Y.; Wang, H.-Y.; Cao, J.-G.; Huang, L.-Q. Chemical Composition and Anti-inflammatory and Antioxidant Activities of Eight Pear Cultivars. J. Agric. Food Chem. 2012, 60, 8738-8744. [CrossRef]

84. Pistelli, L.; Bertoli, A.; Gelli, F.; Bedini, L.; Ruffoni, B.; Pistelli, L. Production of Curcuminoids in Different in vitro Organs of Curcuma longa. Nat. Prod. Commun. 2012, 7. [CrossRef]

85. Dehghan, H.; Rezaee, P.; Aliahmadi, A. Bioassay screening of 12 Iranian plants and detection of antibacterial compounds from Heracleum persicum using a TLC bioautography method. J. Liq. Chromatogr. Relat. Technol. 2020, 43, 381-387. [CrossRef]

86. Welke, J.E.; Zanus, M.C.; Lazzarotto, M.; Zini, C.A. Quantitative analysis of headspace volatile compounds using comprehensive two-dimensional gas chromatography and their contribution to the aroma of Chardonnay wine. Food Res. Int. 2014, 59, 85-99. [CrossRef]

87. Zhang, X.; Yu, Y.; Cen, Y.; Yang, D.; Qi, Z.-C.; Hou, Z.; Han, S.; Chen, Q.; Liu, K. Bivariate Correlation Analysis of the Chemometric Profiles of Chinese Wild Salvia miltiorrhiza Based on UPLC-Qqq-MS and Antioxidant Activities. Molecules 2018, $23,538$. [CrossRef]

88. Kiokias, S.; Proestos, C.; Oreopoulou, V. Phenolic acids of plant origin-A review on their antioxidant activity in vitro (o/w emulsion systems) along with their in vivo health biochemical properties. Foods 2020, 9, 534. [CrossRef]

89. Liaudanskas, M.; Zymonè, K.; Viškelis, J.; Klevinskas, A.; Janulis, V. Determination of the Phenolic Composition and Antioxidant Activity of Pear Extracts. J. Chem. 2017, 2017, 1-9. [CrossRef]

90. Truong, X.T.; Park, S.-H.; Lee, Y.-G.; Jeong, H.Y.; Moon, J.-H.; Jeon, T.-I. Protocatechuic Acid from Pear Inhibits Melanogenesis in Melanoma Cells. Int. J. Mol. Sci. 2017, 18, 1809. [CrossRef]

91. Tanrioven, D.; Eksi, A. Phenolic compounds in pear juice from different cultivars. Food Chem. 2005, 93, 89-93. [CrossRef]

92. Li, X.; Gao, W.-Y.; Huang, L.-J.; Zhang, J.-Y.; Guo, X.-H. Antioxidant and Antiinflammation Capacities of Some Pear Cultivars. J. Food Sci. 2011, 76, C985-C990. [CrossRef] 